\title{
SCOTTISH MEDIEVAL PARISH CHURCHES: THE EVIDENCE FROM THE DIOCESES OF DUNBLANE AND DUNKELD
}

\author{
Richard Fawcett, FSA, Richard Oram, FSA, and Julian Luxford, FSA \\ Richard Fawcett, FSA, School of Art History, University of St Andrews, 79 North Street, \\ St Andrews KYı6 9AL, UK. E-mail: rf4I@st-andrews.ac.uk \\ Richard Oram, FSA, School of History and Politics, University of Stirling, Stirling FK9 4LA, UK. \\ E-mail: r.d.oram@stir.ac.uk \\ Julian Luxford, FSA, School of Art History, University of St Andrews, 79 North Street, St Andrews \\ KYI6 9AL, UK. E-mail: jml5@st-andrews.ac.uk
}

The great majority of Scottish parish churches owe their present appearance to reconstructions carried out from the later eighteenth or nineteenth centuries. It was the view of the authors of this paper, however, that in many cases those reconstructions had been relatively superficial, and that medieval work might have survived under what could, in some cases, be little more than a modern veneer. To test this view, a survey was carried out of all medieval parish sites within the dioceses of Dunblane and Dunkeld. The findings from that survey are summarized in this paper.

The loss of medieval parish churches in Scotland has been so great that there is a widely held view that too few survive for a detailed understanding of pre-Reformation parochial architecture to be reached. In a paper published in 1939, for example, it could be suggested that there were no more than about sixty substantially medieval churches in the whole of Scotland that were still in use for worship. ${ }^{\mathrm{I}}$ As a result of our work in a number of areas of Scotland, however, the authors of this paper have come to the view that a higher proportion of the existing stock of parochial churches than might appear either embodies medieval fabric or has been closely governed by medieval predecessors. ${ }^{2}$ It is also our view that more of the abandoned churches for which structural remains survive are likely to be of medieval date than is generally assumed. Here it should be remembered that the economic situation of the Church in the aftermath of the Reformation meant there was initially little alternative to retaining the majority of medieval parish churches with little change, ${ }^{3}$ and it was only once the fortunes of the Church began to improve that it became possible to consider the general provision of more suitable buildings. The question should be asked how those more suitable buildings were created.

To test these views it was determined that a critical analysis should be undertaken of the fabric and parochial history of all churches and church sites that served parishes of

I. Anderson 1938-9.

2. The detailed results of this project are presented on a website at $<$ http://arts.st-andrews.ac.uk/ corpusofscottishchurches $>$; this paper is based on the conclusions set out in the introductory sections of that website. The website should be consulted for fuller architectural and historical accounts of all of the churches.

3. Howard 1995, 177-88. 
medieval origins; the dioceses of Dunblane and Dunkeld were selected for the pilot stage of what it is intended will be a national survey. The starting point for the study was the list of medieval parishes published by Ian Cowan in $1967,{ }^{4}$ from which thirty-eight sites were identified as having been in the diocese of Dunblane, and sixty-seven in the diocese of Dunkeld, giving a total of I05. Relatively little systematic work has so far been undertaken on the churches within these dioceses and the researchers therefore felt they could approach the work with a minimum of preconceptions. The area also contains a sufficiently wide range of architectural types to merit study, with churches ranging in scale and ambition from the two cathedrals, which were themselves parochial, to buildings of unaugmented rectangular plan. The project was carried out over one year in 2008-9 and the following principal questions were asked: how many of the medieval parishes in these dioceses have retained anything of the pre-Reformation fabric of their churches; how complete a picture can be established of the range of their medieval architectural forms and liturgical provisions; how much can be established of their parochial history, and how far can that be related to the architectural history?

\section{AN OVERVIEW OF THE SURVIVAL OF THE CHURCHES SINCE THE REFORMATION}

Since the majority of churches that serve parishes of medieval origin within the study area now owe more of their appearance to what has happened to them since the Reformation than to their medieval architectural history, a brief overview will first be offered of the range of modifications that many of them have undergone. ${ }^{5}$

\section{Adaptations and losses of medieval church buildings}

At the time of the Reformation, in the years around I560, attitudes towards medieval church buildings were ambivalent. In as much as they were regarded as the focus of idolatrous forms of worship, they were abhorred by leading reformers. The funding base of the reformed Church was not an adequate means for wholesale replacement, however. As a result, and however reluctantly, the need was recognized to preserve most of them in order to accommodate the reformed worship that was to supplant the practices deemed to be unacceptable. ${ }^{6}$ Thus it was that, in 1560 , careful instructions were given to those who were to 'cleanse' Dunkeld cathedral to 'tak guid heyd that neither the dasks, windchs nor durris be ony ways hurt or broken'; the main targets were stated to be 'the altaris and ... monuments of idolatrye'. ${ }^{7}$ It should also be recollected that it took many years for the new forms of worship and church governance to take on a definitive form. At first it seems it was assumed that frequent communion would be as much a feature of worship as more active preaching of the word; ${ }^{8}$ perhaps initially there was no settled view on the architectural forms and arrangement of spaces that would be best fitted to reformed worship.

4. Cowan 1967.

5. For a more detailed discussion of Scottish post-Reformation church architecture, see Hay I957, Howard I995, I69-209, Dunbar I996, Spicer 2000 and Spicer 2003.

6. Spicer 2003.

7. McRoberts I959, I53.

8. Donaldson I984. 


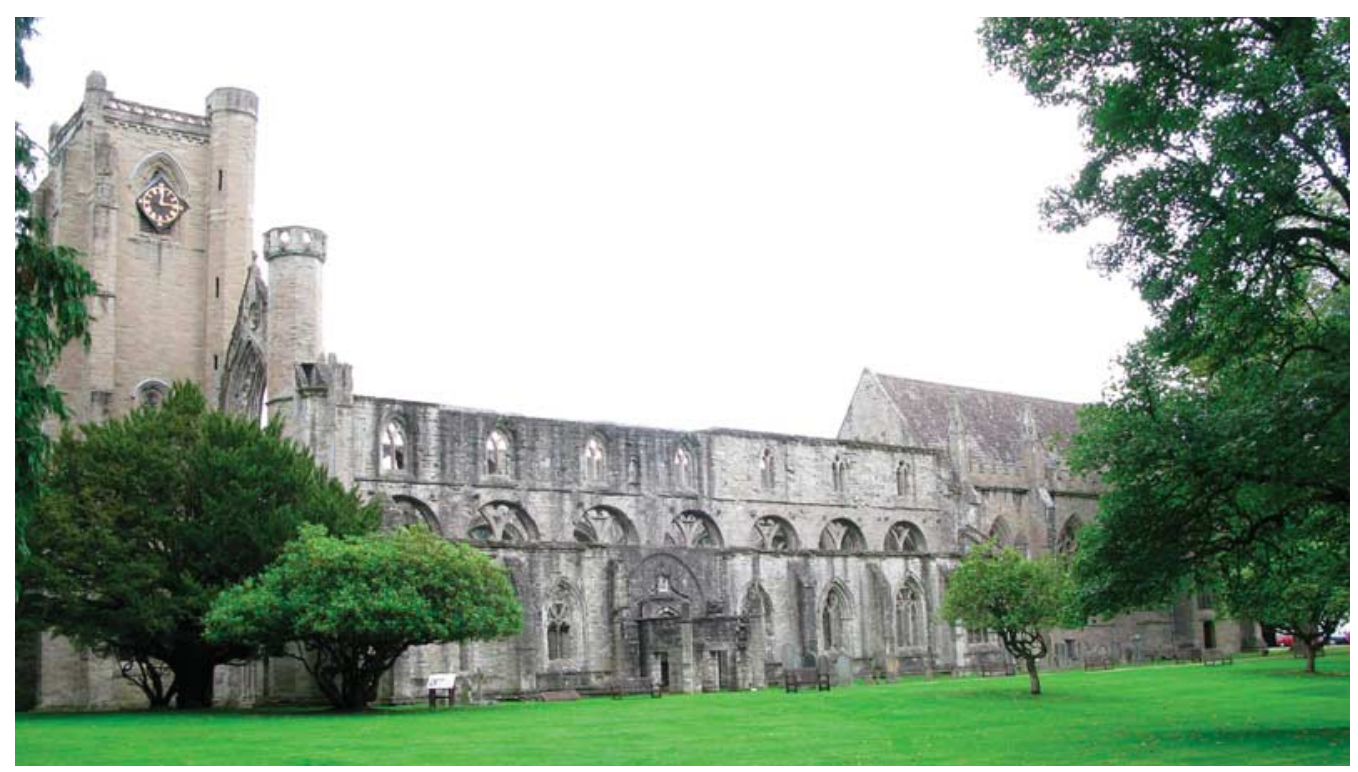

Fig I. Dunkeld cathedral from the south west. The choir, which has remained in use for worship, is to the right of the ruined nave

For two centuries and more after the Reformation the most common response was simply to adapt existing church buildings by extensive internal re-ordering combined with limited additions or excisions. At the largest of the parish churches in the study area including the cathedrals of the two dioceses - this might mean retention of only a part of the building. That retained part was then fitted out to serve as what was, in effect, a preaching hall, with what contemporary descriptions suggest must often initially have been a somewhat haphazard arrangement of seating and galleries focused on a pulpit against one of the long walls. Thus, at the two cathedrals, the laity abandoned the complex aisled space of the nave that had been their previous place of worship, and moved into the spatially simpler rectangular choir (fig I). A slightly different approach was adopted at Culross after the parishioners moved from their old parish church to the more conveniently located Cistercian abbey church; there the presbytery, transepts and monks' choir were adapted for their needs. In a number of the smaller churches - the great majority of which were of elongated rectangular plan with a structurally undifferentiated and oriented sequence of chancel and nave - there may have been some truncation of the length to ensure that as many as possible of the congregation could be within hearing distance of the preacher. It is likely that the part most often forfeited or put to other uses - some of which will be discussed below - was the chancel area. In other cases, however, attempts were eventually made to absorb the chancel into an architecturally more unified structure by rebuilding one or both of its walls on the same alignment as those of the nave, as appears to have happened at Tibbermore in 1789 and at Dunning in 1810 (fig 2).

At both of those churches another expedient aimed at bringing larger numbers closer to the pulpit was adopted in the form of a single large lateral aisle off the flank that faced across to the pulpit. This resulted in a T-shaped plan, an example of which is to be seen at Redgorton (fig 3), while one of the medieval transepts at Culross Abbey probably served a similar function. 


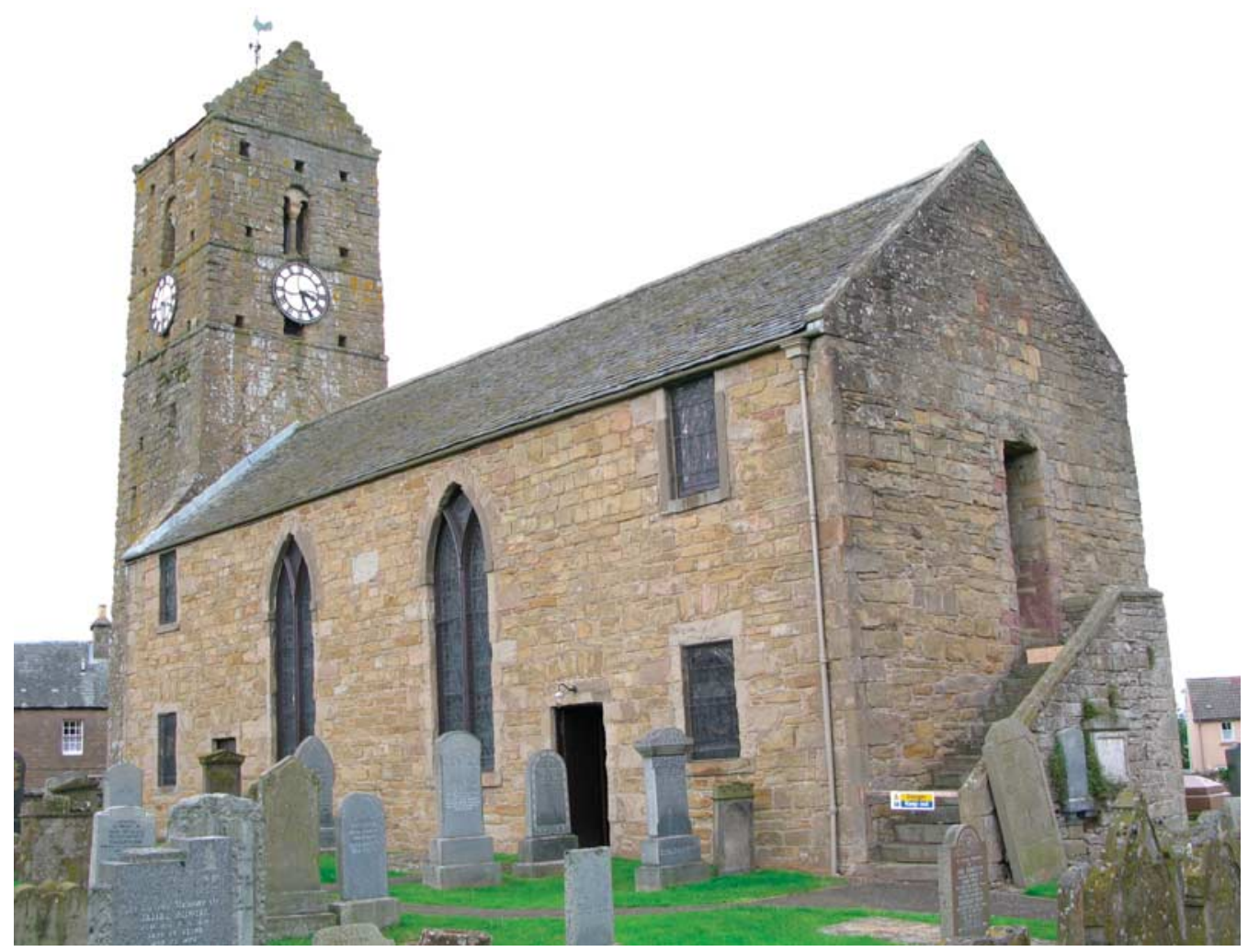

Fig 2. Dunning church from the south east. The structural distinction between chancel and nave was partly suppressed when the south wall was rebuilt in I8IO

A related form of addition was the lairds' aisle; these were built at a number of churches in the course of the seventeenth, eighteenth and nineteenth centuries for the use of local landowners and their households. ${ }^{9}$ Before the Reformation, where a leading family had its own chapel aisle attached to a church - as may probably still be seen at Abernethy and Culross in this study area (see figs 2I and 22) - such chapels had been the place of choice for burial and soul masses for many of the family members. After the Reformation these chapels could still be used, but as a place where the family sat in isolated splendour during parish worship. Just as importantly, since chapel aisles of this kind were deemed to be technically outside the body of the church, there was no impediment to their continued use for family burials. It was presumably for these reasons that such medieval aisles were taken as a model for the new generation of additions. Post-Reformation lairds' aisles usually projected from one of the church flanks, though they might also be set at one end, as is the case at Dalgety (fig 4). The opening towards the body of the church from the aisle might be given particular emphasis in deference to the social standing of those who occupied the aisle, while the seating area was often elevated above the general floor level. At a lower level there was frequently a carefully constructed burial vault, which might be wholly or partly above floor level, as at Aberdour and Dalgety. 


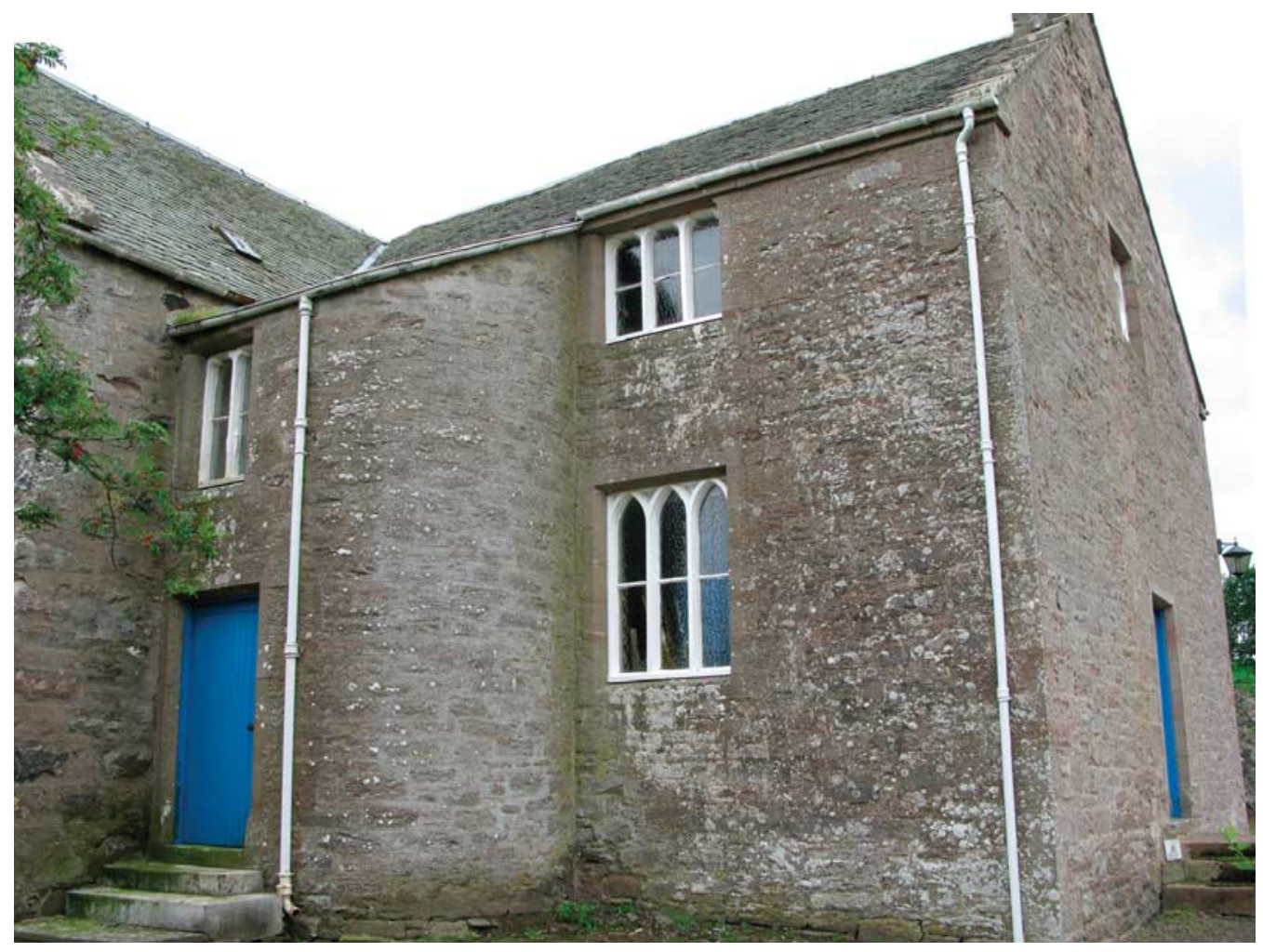

Fig 3. Redgorton church from the north east, showing the aisle added on the north side of the church in 1839

There was yet another way in which the leading figures of a parish might secure burial rights within a church. James VI's Act of Annexation of I587 had an incidental consequence that those land-holders who were granted the temporal lordships of the old religious houses also acquired responsibility for - and effective ownership of - the chancels of the parish churches appropriated to those religious houses. ${ }^{\text {IO }}$ In cases where the newly endowed temporal lords were resident in the parish they sometimes chose to construct their family pew within the chancel, with a vault below it for their dead, making it into what was essentially an eastern laird's aisle. Alternatively, they might prefer to wall off the chancel to create an enclosed family mausoleum. The situation with regard to chancels was further formalized in 1633 , when Charles I enacted that the parochial teinds (tithes) should pass to the heritors (principal land-holders), who thus became responsible for the fabric of the church and the provision and maintenance of the minister. ${ }^{\text {II }}$ It was this change of effective ownership that lay behind the construction of the splendid loft of the Hope of Hopetoun family at the east end of Abercorn church (fig 5), for example, and is the reason why the Lords Rollo had a loft in Dunning church chancel (see fig 2), approached by a forestair against the east wall. It also allowed the Robertsons of Lude to have their loft in the chancel area of Kilmaveonaig church. However, as has often

Io. Thomson I844, 43I-6.

II. Cormack I930, 98-I08; Donaldson I97I, 296-8, 400. 


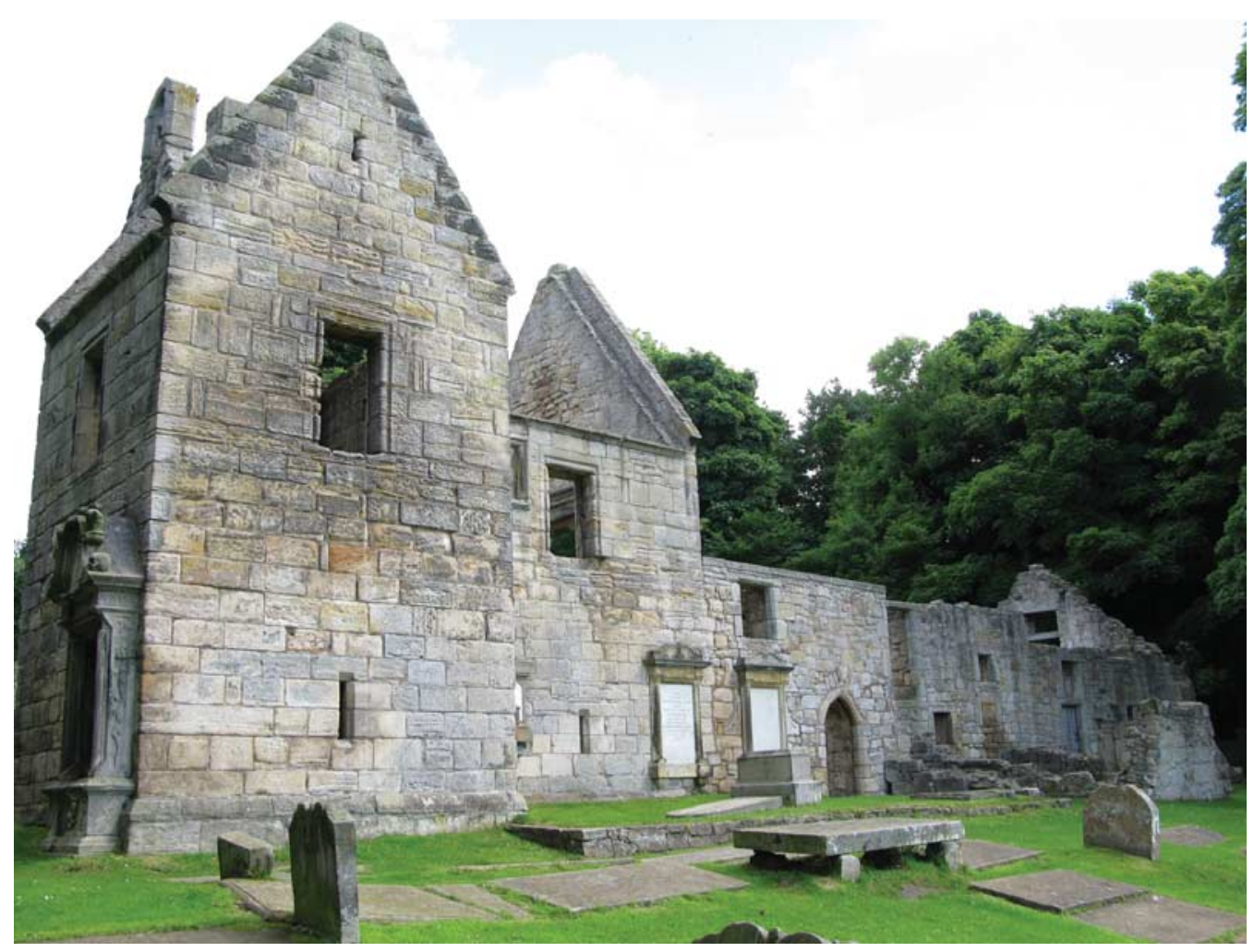

Fig 4. Dalgety church from the south west. The enormous two-storeyed laird's aisle of the first earl of Dunfermline extends from the west end of the rectangular medieval church, while the fragments of another laird's aisle project from the south flank

happened, the last of those has been removed in response to the ecclesiological revival in the decades around I900, one aspect of which was a desire to relocate the communion table to the site of the medieval altar.

Not all of the inherited medieval buildings could be put to use by the Reformed Church, however, and amongst the earliest losses were those that resulted from parochial restructurings. Although the geographical pattern of parishes as established in the twelfth and thirteenth centuries continues to provide the basis for the territorial organization of the Church of Scotland, that pattern has always been subject to modification. In the years following the Reformation, and at a number of subsequent periods, a combination of pastoral and financial considerations resulted in attempts to rationalize parochial boundaries, with some churches consequently being found to be superfluous to requirements. The course that such considerations might take at one stage is well documented in a report prepared in 1628 as part of Charles I's efforts to place the Scottish Church on a firmer financial and organizational footing. ${ }^{\text {I2 }}$

I2. Macdonald I835. Amongst churches in the study area abandoned as a consequence of parochial adjustments were Aberuthven, Ardeonaig, Crombie, Fossoway, Kilbryde, Lagganallachie, 


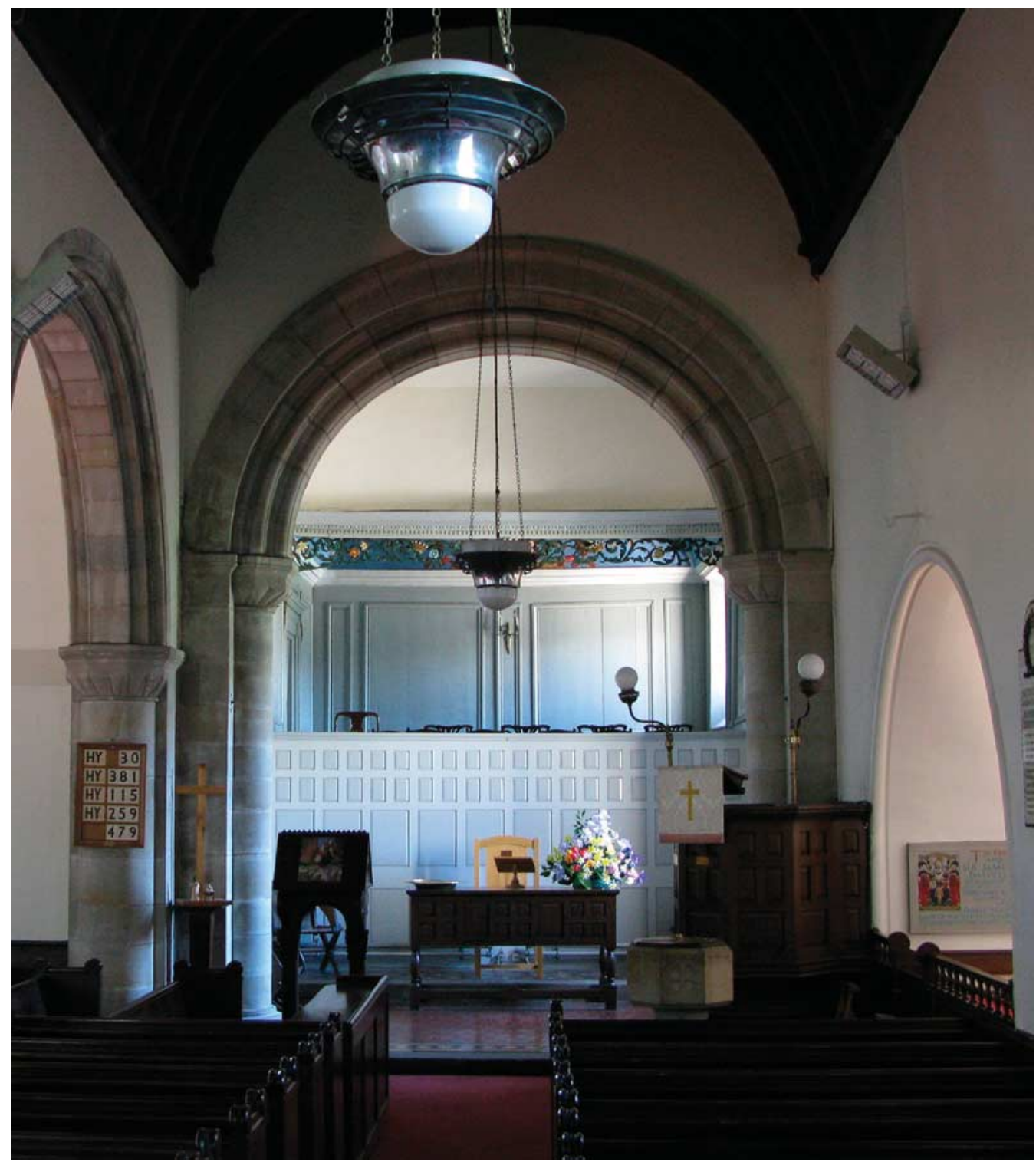

Fig 5. Abercorn church: the interior looking east. The Hopetoun loft of 1708 is in the chancel, and on the right can be seen the entrance to Dalyell of the Binns Aisle. The chancel arch dates from 1893

At the great majority of churches that continued in use, the willingness - or unavoidable need - to make do and mend with an inherited medieval building appears to have worn increasingly thin from the later eighteenth century. This was perhaps at least

Lethendy, Logiebride, Lude, Monzievaird, Muckersie, Obney, Preston, Rosyth, Strowan, Tullibody, Tullibole and Tullichettle. 
partly because of chronic shortcomings in the maintenance of the buildings by the heritors. Many would have echoed the complaint of the minister of Little Dunkeld in the I790s that his church was 'mean, uncomfortable and ruinous'. ${ }^{13}$ There is also evidence of a growing view that, while it would be wrong to see anything inherently sacred in the building itself, the house of the Lord should nevertheless be sufficiently seemly for such an exalted purpose. Many existing buildings were simply regarded as not lending themselves well to worship in which preaching was the central element. The stated view of the minister of Clunie that 'it would be a credit to this country if all the old crazy kirks and manses in it were razed to the foundations, and new ones built in a workmanlike manner, on a decent and convenient plan, and of the most substantial materials' probably represented the feelings of many hard-pressed ministers. ${ }^{\mathrm{I} 4} \mathrm{~A}$ principal complaint of some ministers was the elongated proportions of the medieval churches they had inherited, as at Auchtergaven, where it was said that 'its length [was] disproportioned to its width', ${ }^{15}$ or at Fortingall, where the concern was that the building was 'rather inconveniently narrow'. ${ }^{16}$

It was largely because of such attitudes that a high proportion of churches eventually came to be so extensively remodelled or entirely replaced by new buildings. If a contract for rebuilding the small church at Abernyte may be taken as illustrative of requirements, it seems that the preferred proportions for new churches involved a length that was no more than twice the width. In the case of Abernyte the contract specified dimensions of 40 by 2oft (I2.I9 by 6.Im). ${ }^{17}$

In considering losses of medieval buildings it should be mentioned here that the situation is once again changing, as the Church of Scotland struggles to deal with overprovision of church buildings for its current needs. In this there are perhaps two principal factors. On the one hand a high proportion of parishes have more than one church building because of the secessions that have taken place in the past, and especially as a result of the Disruption of $\mathrm{I} 843$. On the other hand, declining attendances mean that it is barely viable to maintain some buildings, especially in many of the poorly populated rural communities that figure so prominently in the area covered by this study. As a consequence, many churches have passed out of use for worship within recent decades, while the future of others hangs in the balance. ${ }^{18}$

\section{Churches remodelled or replaced by new buildings on the site of the} medieval church

When replacing an existing church, two considerations were perhaps at the forefront of the minds of those involved. Should it be rebuilt on the footprint of the existing church, in which case there might be economies in the re-use of foundations, and probably also of walls, or should it be rebuilt on another site, which might have the advantage of allowing services to continue without break in the old building until the new one was ready to be brought into use, unless the old materials were to be recycled? The former course must

13. Sinclair I79I-9, VI, 37I.

I4. Ibid, IX, 253.

I5. Ibid, XVII, 552.

16. New Statistical Account of Scotland 1834-45, 10, 555-6.

17. Heritors' Records, cited in Historic Scotland's list of Historic Buildings.

I8. Amongst churches abandoned in recent decades are Alva, Cargill, Comrie, Crieff, Dron, Dull, Dunning, Kinloch, Leslie, Moneydie, Moulin, Redgorton, Tealing and Tibbermore. 


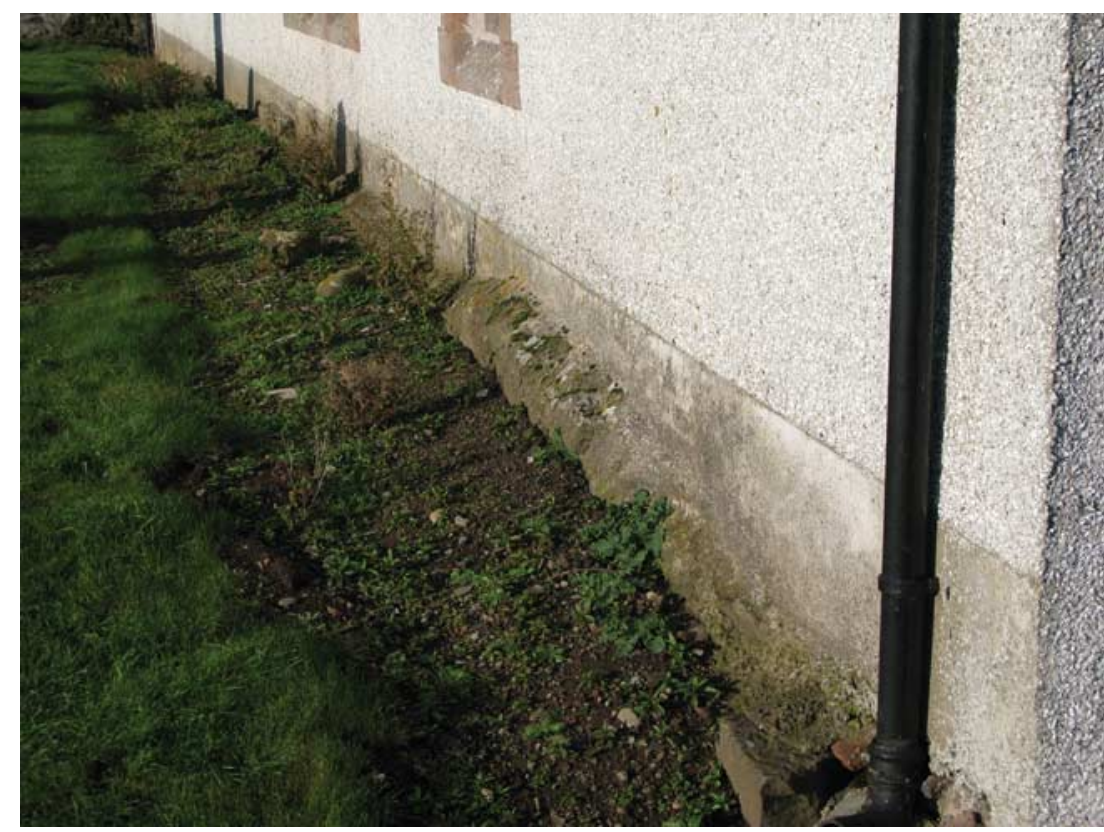

Fig 6. Madderty church, showing the earlier foundations projecting below the south wall

frequently have been favoured by the heritors, who in many cases - and especially before the era of rebuilding on a more heroic scale gathered momentum around the middle years of the nineteenth century - were generally not keen to spend more than was strictly necessary. The latter course was presumably more attractive to those ministers who had not been infected by an antiquarian interest in their church and its history.

Whichever course was adopted, it hardly needs pointing out that, in the absence of documentary evidence and the ability to carry out invasive analysis, it can now be very difficult to know whether or not a church is on the site of its predecessor. It is only in cases such as Madderty, where what appear to be earlier footings project from beneath parts of the wall, that we may strongly suspect the new church has been raised above old foundations (fig 6). A process of this kind may be documented at Aberfoyle, where a contract of $1743^{-4}$ stipulated that the church was to be rebuilt from the foundations, though inspection of the masonry suggests that parts of the earlier walling were in fact also retained there. ${ }^{19}$ In some cases most of the shell of the earlier building has clearly been retained. At Fowlis Wester, for example, in the course of restoration in 1927 a relatively coherent series of earlier features was found behind the external render and the internal plaster that covered the walls, indicating that a church which had all the appearance of being a complete rebuilding of $\mathrm{I} 8 \mathrm{O} 2$ was in fact essentially no more than the remodelling of a medieval building (fig 7). There is a strong possibility that many other churches within the study area have been treated in the same way.

Even at buildings with the compressed proportions that appear more appropriate for a post-Reformation than for a medieval place of worship, it is possible that medieval work 


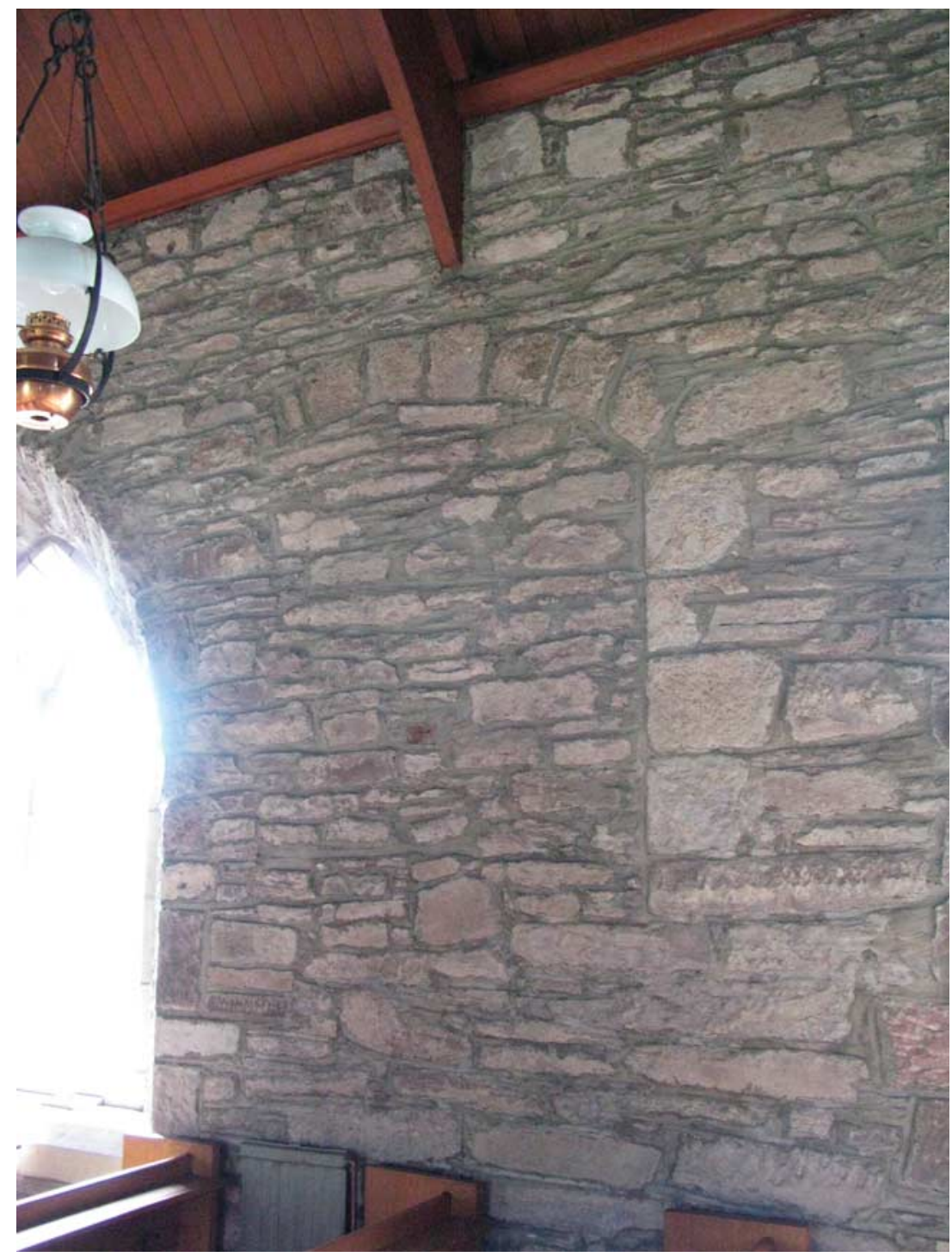

Fig 7. Fowlis Wester church, showing traces of an earlier window rear arch in the south wall

has been retained. The process described at Moulin, whereby in I 704 the 'front wall' was taken down and the church widened, indicates one of the approaches that might be followed (fig 8). ${ }^{20}$ At the demolished church of Alva, the core of a building that was successively augmented on a number of occasions was quite precisely oriented, and its length of $21.55 \mathrm{~m}(70.6 \mathrm{ft})$ was what might be expected in a medieval parish church. Yet the width of that core, which was II.45m (37.5ft), was closer to the 2:I proportion evidently

20. Sinclair I79I-9, v, 65 . 


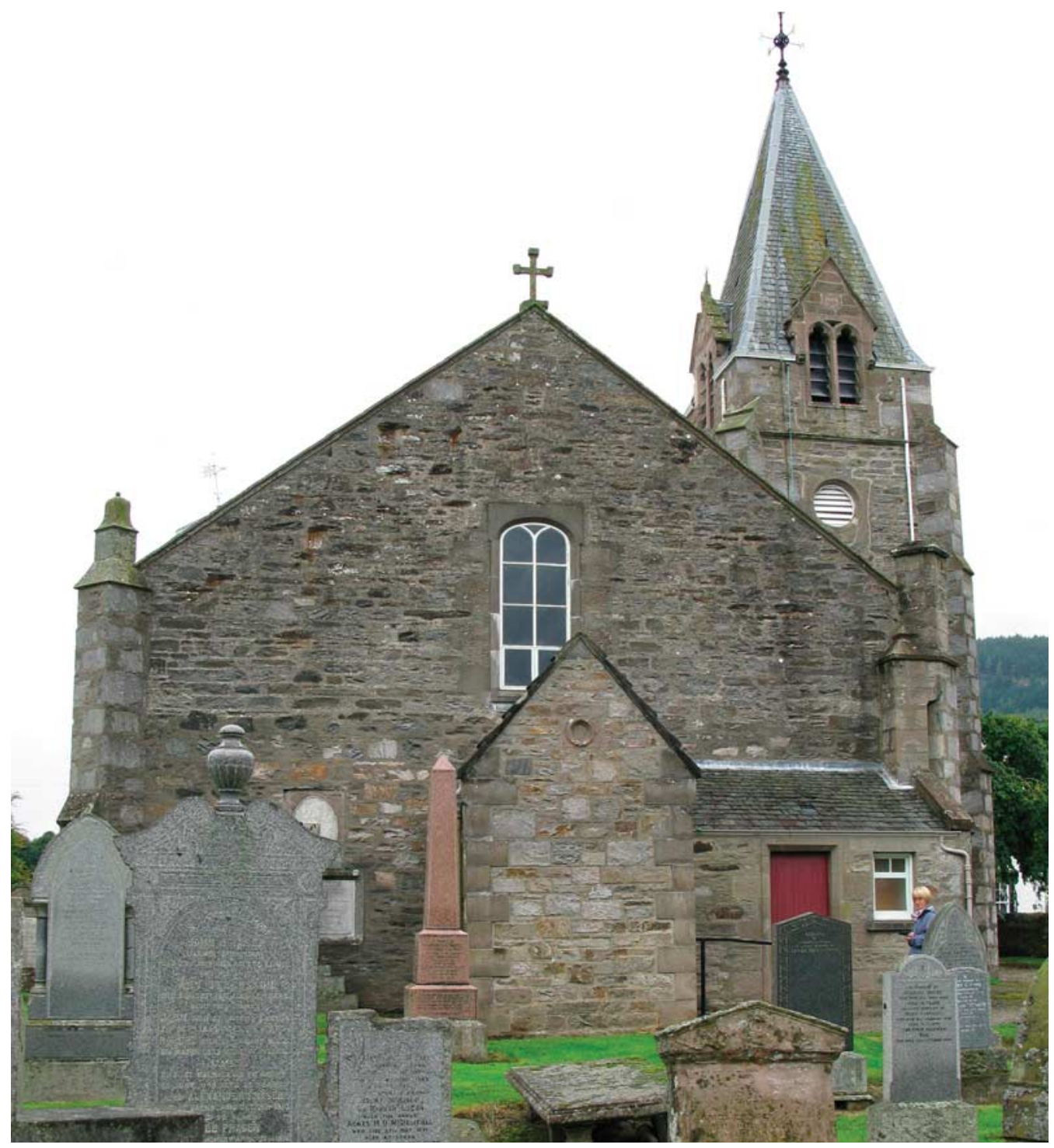

Fig 8. Moulin church from the east; this church was widened in 1704

favoured for preaching halls, and it must be considered as a possibility that it had undergone the same process of widening as Moulin. In such cases parsimony was probably one consideration that prompted the heritors to keep as much as possible of an existing building. Returning to Moulin, it is recorded that in 1787 the windows were enlarged, the walls plastered and the roof ceiled, with the consequence that, as at Fowlis Wester, the building would have acquired a fully Georgian appearance, with nothing visible to make evident its medieval antecedents.

We must be thankful that there are at least some cases in which areas of patently medieval fabric have been left in evidence at churches that were otherwise extensively remodelled, as a reminder that superficial appearances can be highly misleading. 


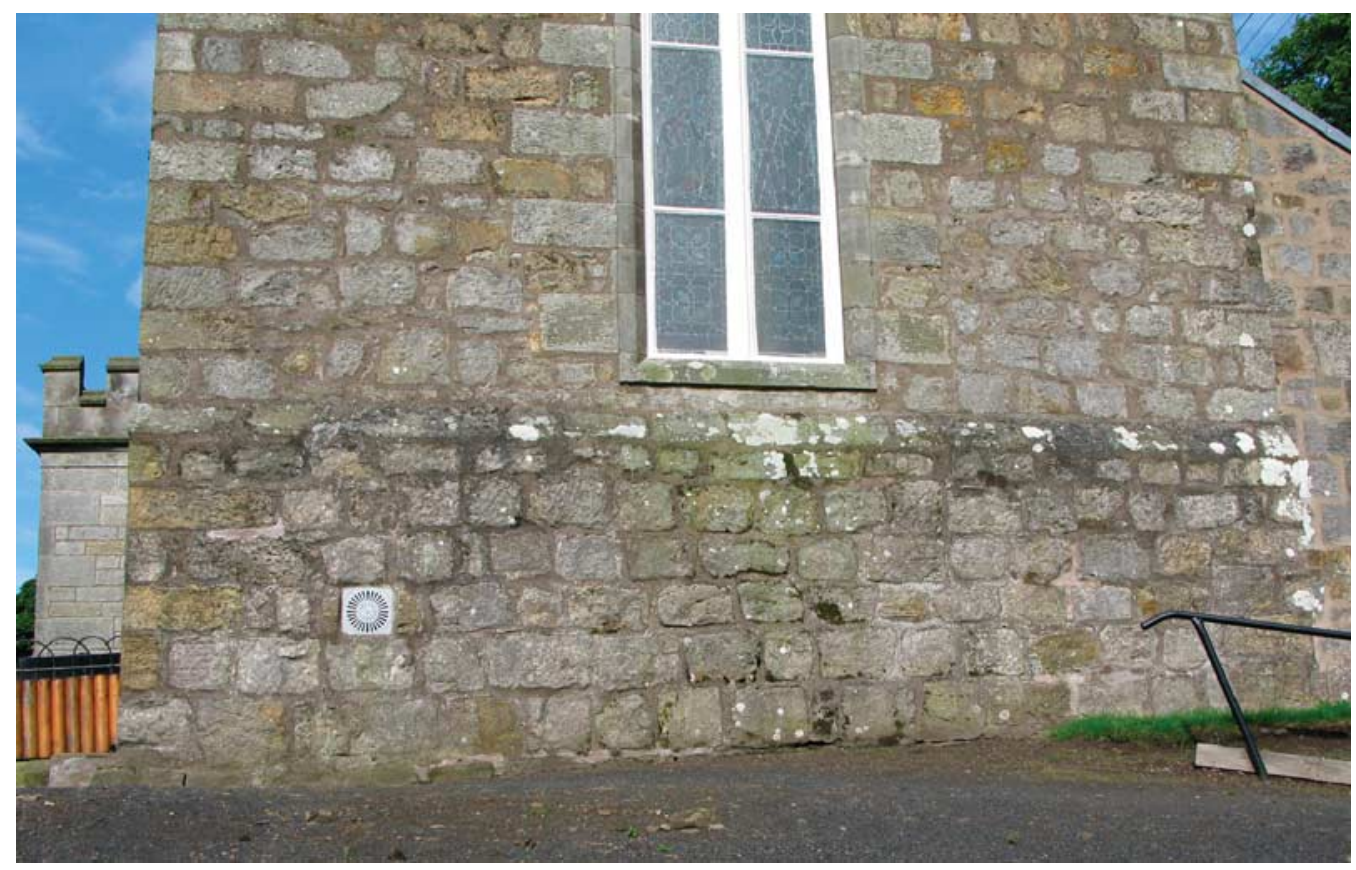

Fig 9. Auchtertool church, showing the earlier masonry and base course along the east wall

At Abercorn, Auchtertool (fig 9), Bendochy, Forgandenny (see fig I6) and Muckersie, for example, the east walls show clear evidence of medieval workmanship, while at Auchterhouse an unusually large number of medieval fragments are to be seen either in place or re-set into later work (see figs I8 and 29).

\section{Churches replaced by new buildings on a different site}

It has been suggested above that a particular attraction of building a new church on a site adjacent to the old one was that it might entail no interruption to worship. However, this cannot have been what took place in those cases when the materials of the old church were recycled in the new one, as can be seen to have happened at Abernethy and Bunkle, for example. In such cases the requirement for continuity of worship within the old church was presumably sacrificed to considerations of economy, and a search through the heritors' records may indicate how worship was conducted while the new church was under construction. A particular disadvantage of building on an adjacent site within the established churchyard was the virtual inevitability of disturbing burials, some of which may have been of quite recent date. At Aberdalgie, when a new church was built in I773, it seems that this problem was avoided by extending the churchyard to provide a new space for the new building. The same appears to have happened at Balquhidder.

In other cases, the clue to the possibility that the church was once on a different spot within the churchyard is the existence of linear mounds, where the walls once stood, or of a level platform, together with either an absence of memorials or the existence only of 


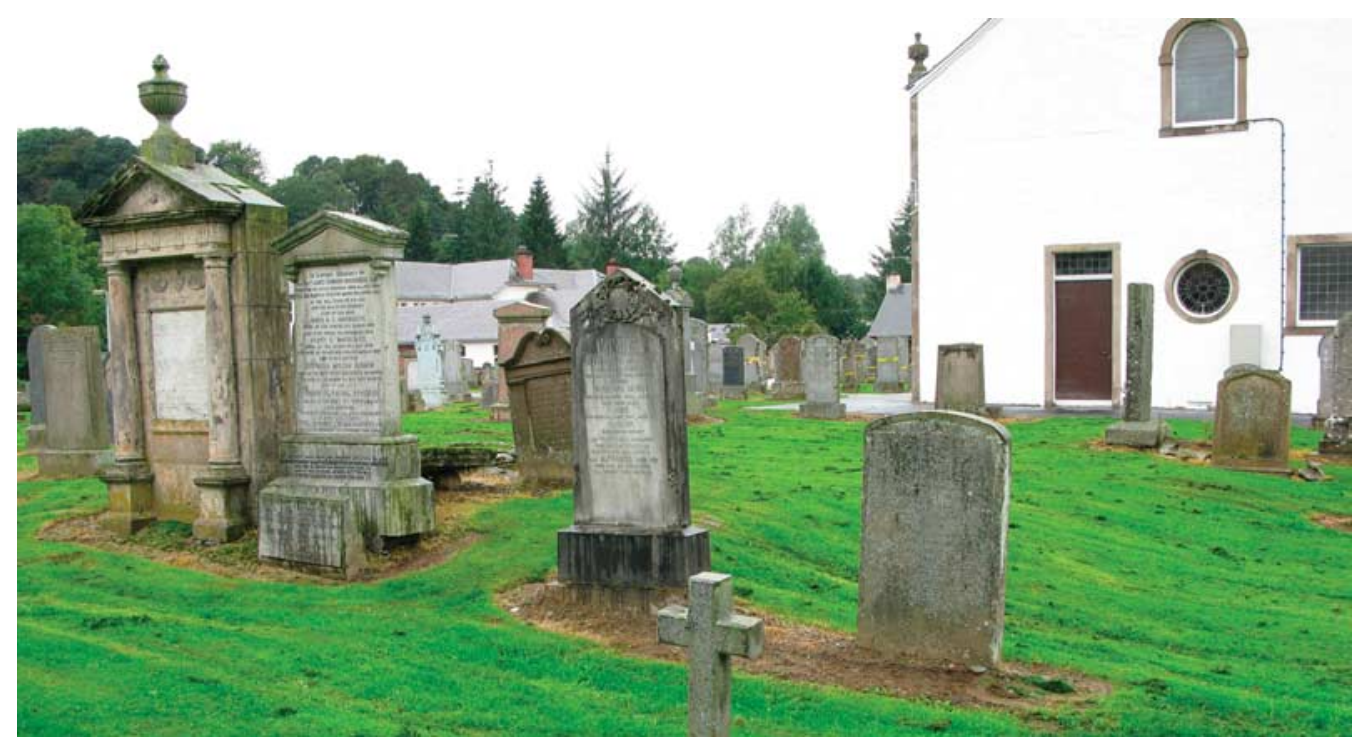

Fig Io. Little Dunkeld church from the north east. In the churchyard, to the east of the church of 1797 , are the faint traces of the lines of the earlier church walls; the monument to the left may have stood against the east wall of that church

memorials of dates subsequent to the rebuilding. At Little Dunkeld the pair of parallel linear mounds to the east of the present church, and on a slightly different axis, almost certainly marks the site of the medieval church, while what appears once to have been a mural monument against the east wall has been left in isolation (fig IO). At Fern there is a platform a short distance to the south of the church, together with a local tradition that the church used to be in the middle of the churchyard. ${ }^{2 \mathrm{I}}$ There is a similar situation at Struan, where the platform is immediately to the south of the later church, and at Trinity Gask there is also a slight platform to the south of the church of 1770 , raising the possibility that the site of the church has been shifted. In such cases geophysical survey is likely to be of great benefit in determining if the church has indeed been relocated within its graveyard.

When a completely new church was to be provided it was sometimes easiest to select an entirely new site, especially if the church to be replaced was not very conveniently sited for the main settlements of the parish. In some cases the move was prompted by the expansion of the parkland of the local landholder, as appears to have been the case at Blair, Findo Gask, Kenmore and Kippen. Whatever the reason, the new church was built within the sight of the old one in the majority of cases.

\section{Churches that have at least partly survived through mortuary use}

At a number of sites where the church was relocated, parts of the old building were allowed to remain in place adjacent to its successor. At Muckairn, a geographically isolated 


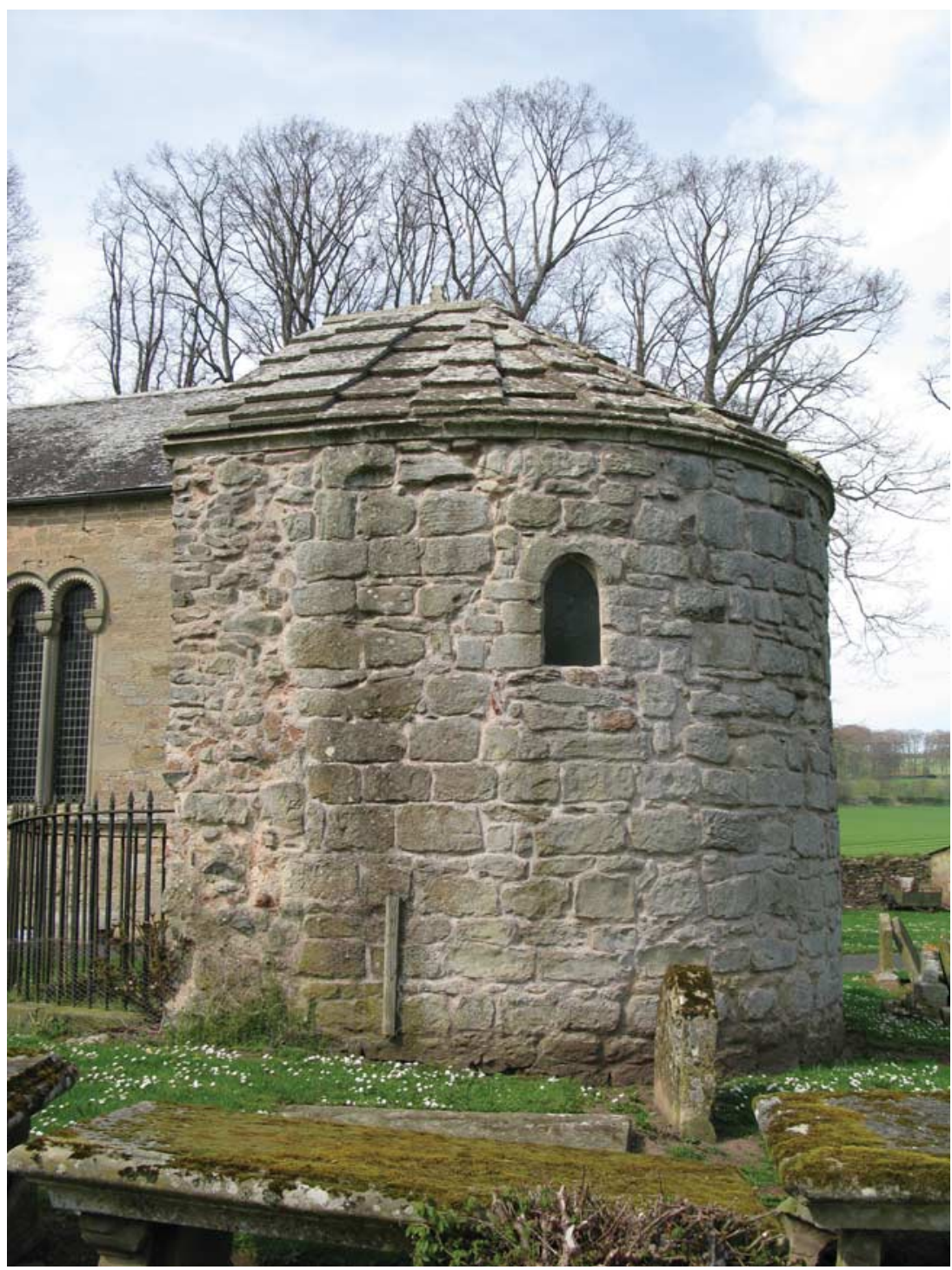

Fig II. Bunkle: the apse of the twelfth-century church from the south; the church that replaced it in 1820 is in the background

reminder of the period before the II 80 s when the diocese of Dunkeld extended to include the area later cut off to create the diocese of Argyll, the east gable and part of the south wall of the old church stand to the south of its replacement. Similarly, at Balquhidder the shell of the old church stands a short way to the south of its successor. Within the graveyard at Bunkle there is the apse of the early twelfth-century church, a unique survivor of such an eastern termination in the area of this study, which was adapted as a burial enclosure by the Home of Billie family (fig II). At Leslie a new church was built to the south of the old one, the latter being then demolished, though two burial aisles likely 


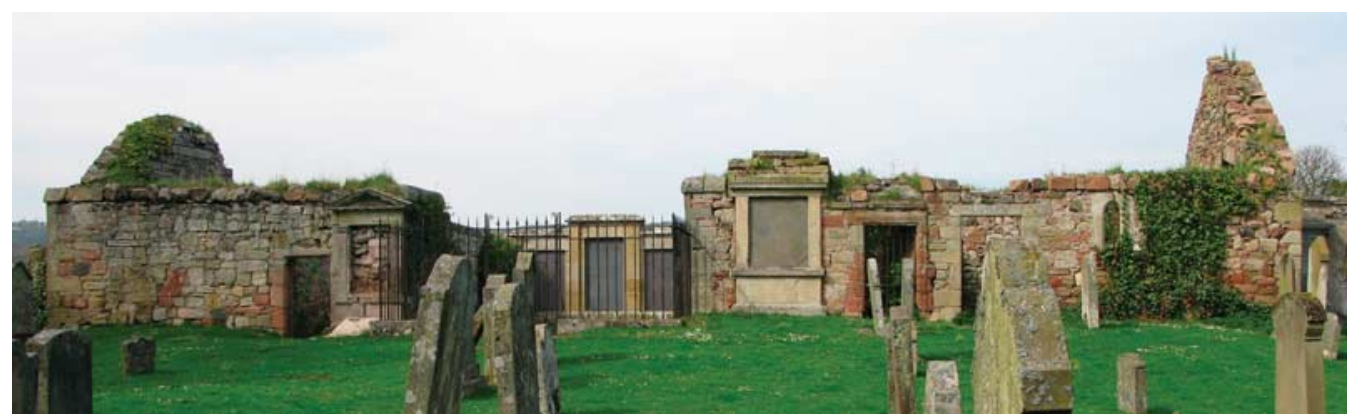

Fig I2. Preston church from the south; this church survived as a result of subdivision into a number of burial enclosures

to be of seventeenth-century origin that had projected from the north side of the old church were left in place.

As was the case at Bunkle and Leslie, the most common reason for the retention of part of an earlier church building was its use for burials; in some cases this must have been a continuation of an existing situation where a family had jealously guarded burial rights in a part of the building. Before the Reformation, many of the clergy and leading parishioners would have expected to be buried within their church, where their tombs might attract prayers for their salvation; after the Reformation, changed attitudes to death and the efficacy of prayers for the dead meant that intramural burial was frowned upon. ${ }^{22}$ Ways could be found around this, however, and recent excavations within the burgh church of Aberdeen, for example, have revealed large numbers of post-medieval burials within the chancel, which had been adapted as the East Kirk for one of the congregations that worshipped in the subdivided building. ${ }^{23}$ As has already been shown, there might also be more generally acceptable ways of securing burial within the walls of a church, if a family had its own aisle or had rights within the area that had been the chancel.

When a church fell out of use for parish worship, family piety and a sense of tradition must often have meant there was a natural inclination to continue any pre-existing mortuary use. This in turn was likely to attract other families to do likewise in other parts of the abandoned building. Where adaptation of this kind was being undertaken, it generally made good sense to retain as much as possible of the surviving walls, and a high proportion of those medieval churches that have come down to us as roofless shells have survived in identifiable state as a result of such use, as at Preston (fig I2). In some cases, however, the medieval building was progressively so completely modified or rebuilt that it is difficult to identify medieval fabric with anything approaching certainty. ${ }^{24}$ Indeed, in exceptional cases an entirely new mausoleum might eventually be constructed on the site of part or the whole of the medieval church, leaving nothing at all in evidence of the earlier building, as at Tulliallan (fig 13 and see fig I4). ${ }^{25}$

22. Spicer 2000 .

23. Cameron 2005.

24. This appears to be the case at Abernethy, Caputh, Cargill, Lagganallachie, Kincardine and Leny.

25. This also happened at Kilbryde and Monzievaird. 


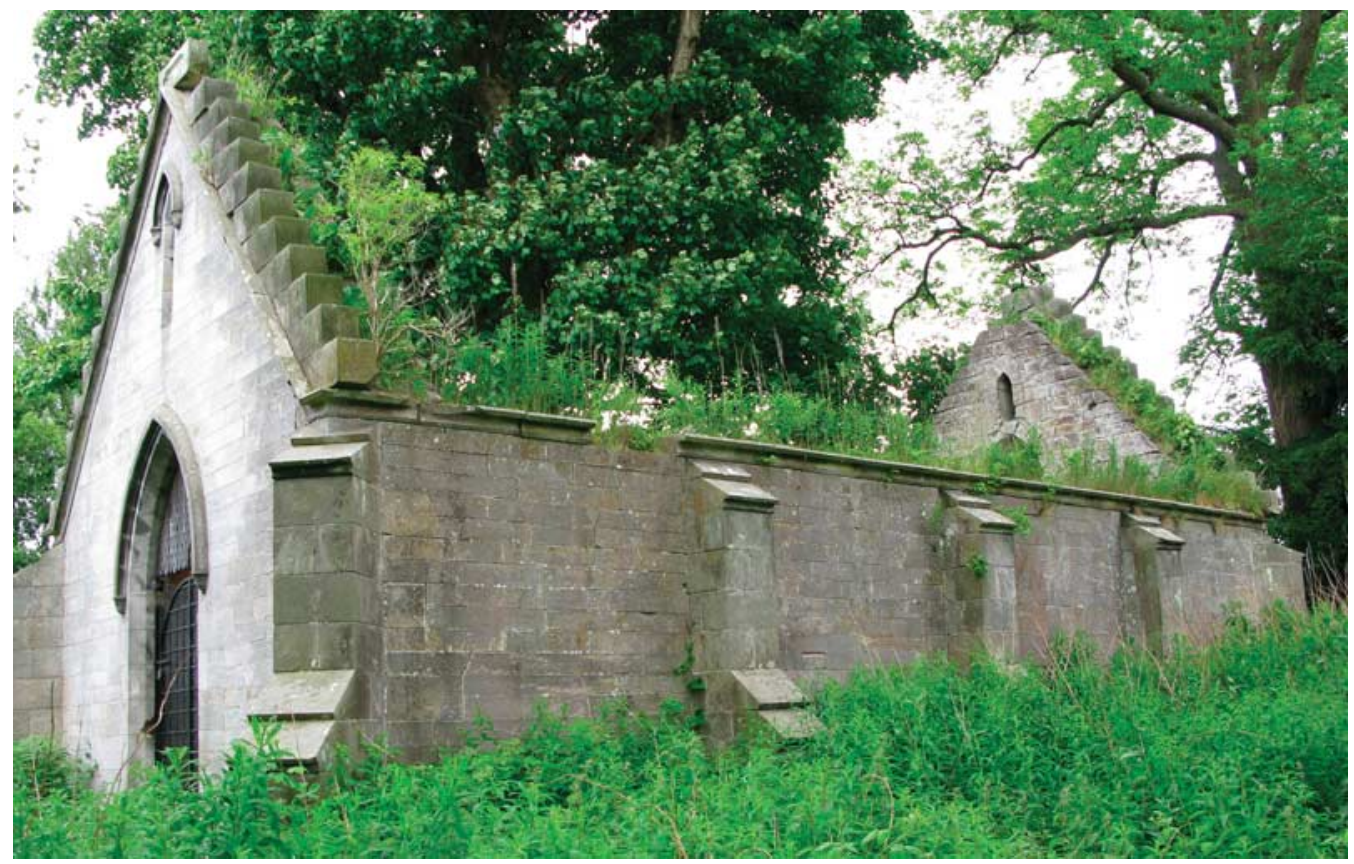

Fig 13. The Keith mausoleum at Tulliallan of 1830 , which is on the site of the medieval church

Whatever the initial good intentions, however, later maintenance of churches that had been adapted for mortuary use was often inadequate, especially if the families concerned died out or moved away, and in some cases the walls of the building were progressively lost. Occasionally, even when the church itself is lost, the line of one or more of the walls is still indicated by the survival of mural monuments that have continued to be maintained, occasionally with tidied-up sections of wall immediately behind them to provide some measure of support, as at Caputh and Little Dunkeld (fig I4 and see fig IO). ${ }^{26}$

\section{THE EVIDENCE FOR MEDIEVAL CHURCHES}

\section{The documentation of building operations}

Having considered something of the range of vicissitudes that have resulted in the extensive transformation and loss of medieval churches in the study area, we must now take stock of the evidence for their medieval state, starting with the documentation associated with their construction. For the most part this is rather disappointing, chiefly because of the loss of administrative records such as episcopal or archidiaconal visitation accounts, rental books and the financial accounts of the pre-Reformation secular Church.

26. This also appears to have been the case at Saline, amongst others. 


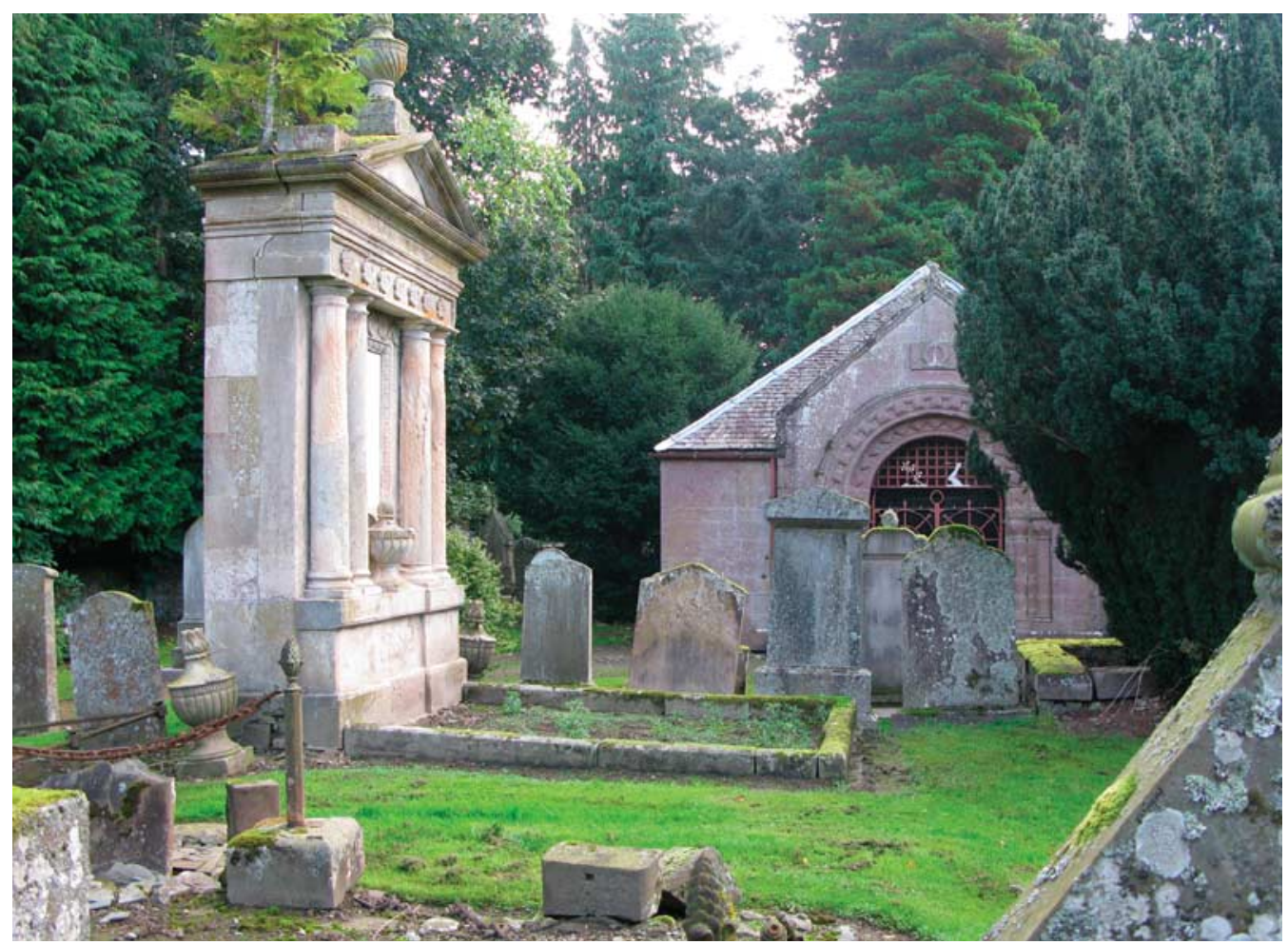

Fig I4. The site of the church at Caputh from the west. The line of the north nave wall may be perpetuated in the location of the monument to John Hagart of Glendelvine on the left. The Mackenzie of Delvine burial vault in the background is a remodelling of the medieval chancel dating from 1879

Nevertheless, there is important financial material surviving for the early I500s from Dunkeld diocese and some evidence for visitations is preserved in notarial protocol books, albeit again largely for the post-I500 period. As might be expected, the major building operations are better documented than the lesser ones, though, even in those cases, there is hardly a plethora of information. The main phase of works at Dunblane cathedral, for example, is datable by nothing more than the assumed terminus a quo suggested by the agreement reached over its finances following a papal mandate of I $237,{ }^{27}$ together with a much later statement in Scotichronicon that Bishop Clement (I233-59) had built it up as a hallowed sanctuary. ${ }^{28}$ There is a little more evidence for the later, relatively minor, works initiated by the Chisholm dynasty of bishops, which is supported in some cases by heraldry, ${ }^{29}$ and supplemented by royal gifts of silver to masons in I5OI-2. ${ }^{30}$ But any understanding of the building chronology must rely largely on close analysis of the architectural evidence. There is a similar situation at Inchmahome priory, which may

27. Theiner 1864 , no. xci.

28. Bower I987-98, v, $32 \mathrm{I}$.

29. McRoberts I97I, 37-52.

30. Dickson et al I877-1978, II, 97, I37. 
have been founded on the site of an existing parish church, and where we can only assume that the church was built as funds allowed, following the foundation of the Augustinian community in or around $1238 .^{3 \mathrm{I}}$

The situation is better at Dunkeld cathedral, due largely to an invaluable account of the lives and activities of its bishops by Alexander Myln, abbot of Cambuskenneth (1519-48) and Lord President of James V's College of Justice, who had earlier been Dean of Angus and Official of the diocese of Dunkeld. ${ }^{32}$ Myln's account appears to be generally accurate for works carried out from the fifteenth century onwards, and to an even greater extent than at Dunblane, there is - or has been - heraldry to supplement the documentary evidence. However, the corporate memory of the cathedral chapter, on which Myln presumably had to rely heavily, appears to have been defective for the earlier phases of building. It would be difficult, for example, to accept Myln's statement that Bishop William Sinclair (1309-37) was indeed responsible for the construction of the choir, since the architectural evidence strongly points to a date around the second quarter of the thirteenth century for that part.

Myln was particularly anxious to chronicle the energetic episcopate of George Brown (1483-I5I5), in whose time he had himself served the diocese. Brown had done much to ensure that parochial cure was provided as effectively as possible, and this extended to works on a number of churches, the construction of at least one of which resulted from his subdivision of parishes. Myln tells us that Brown paid for the construction of the church at the newly founded parish church of Dowally (fig I5), while at Caputh (see fig I4) he funded the building and decoration of the choir, providing a painted reredos and windows. At Pitcairn and Tibbermore he is said to have restored and built the churches. ${ }^{33}$ Some supporting documentation for Myln's references to this architectural activity is to be found in the surviving accounts of diocesan officers, and particularly of the Granitar (the officer responsible for collecting the grain rent), who was charged with funding this aspect of episcopal activity. In I506 there were payments for roofing the church at Dowally and for repairs to the choir at Strathmiglo, while in I508 there were repairs to the choir at Tibbermore, where the bishop had one of his residences. ${ }^{34}$ In 15 IO payments were made for work on windows at Caputh, Cargill and Dowally. ${ }^{35}$ But perhaps the most interesting - and most tantalizing - account in that year is for repairs to the east wall of Tibbermore church, since these were said to have been carried out by a carpenter named as John Fendour. ${ }^{36}$ It is presumably likely that he was the wright of the same name who contracted for highly prestigious works at the burgh church of Aberdeen in I495 and I5IO, ${ }^{37}$ and in I5II for the central spire of Aberdeen cathedral. ${ }^{38}$ In I5II there were payments for building and glazing the choir at Aberlady and for roofing the choir at Preston (see fig I2), and in 1513 repairs were carried out at Forgandenny and again at Tibbermore. ${ }^{39}$

Regrettably for our present purposes, however, almost nothing of Brown's recorded activity on the parish churches of his diocese has left any identifiable trace. At Aberlady

3I. Innes I847, xxxi.

32. Thomson 1823 .

33. Ibid, $42-4$.

34. Hannay I9I5, 89, I98, 207.

35. Ibid, I09.

36. Ibid, 213.

37. Stuart I844, 77-8, 80. See also Kelly I933-4.

38. Littlejohn I904, I02.

39. Hannay I9I5, II-I2, 23I, 259. 


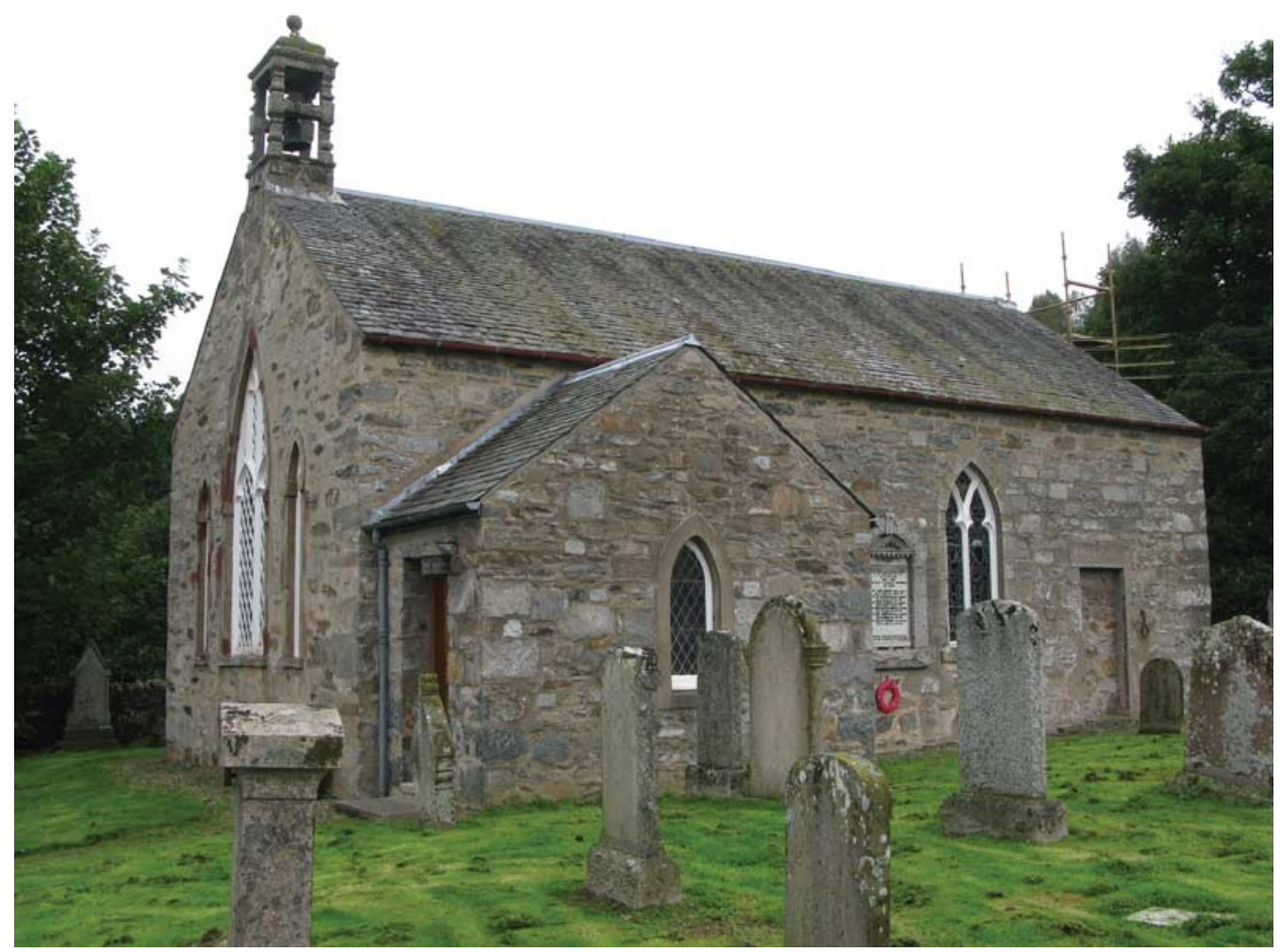

Fig I5. Dowally church from the south east. This church, which has been truncated, was under construction for Bishop George Brown in I5IO

the medieval church has been entirely rebuilt, apart from the west tower. At Caputh the chancel survives as a mutilated fragment remodelled as a burial enclosure, and this may also be the case at Cargill. The medieval church at Dowally probably closely conditioned the present rectangular building, but the only identifiably medieval fragment is a badly weathered relocated heraldic stone that may have borne Bishop Brown's arms. To an even greater extent than at Dowally, the overall form of Forgandenny church probably reflects that of its medieval predecessor (see fig I6), but there is nothing that could be specifically associated with Brown's activity with any confidence. The church at Pitcairn has been lost without trace, and, although Preston survives as an abandoned shell (see fig I2), Brown's choir roof is long gone. As at Pitcairn, the medieval church at Strathmiglo is lost without trace. Most regrettably of all, any remnants of John Fendour's work at Tibbermore must have been destroyed when the chancel was completely rebuilt in 1789 .

A second strand which offers some insight into phases of building development is the record of the foundation of chapels and associated chaplainries, which often had a primarily chantry function. While none of the non-cathedral parish churches in the study area acquired the proliferation of such chapels that is recorded for the major Scottish preReformation urban parish churches - as, for example, at Aberdeen St Nicholas, Dundee St Mary or Perth St John - several did see the later medieval establishment of at least one additional altar in an aisle appended to the main structure. Such additional chapels within 


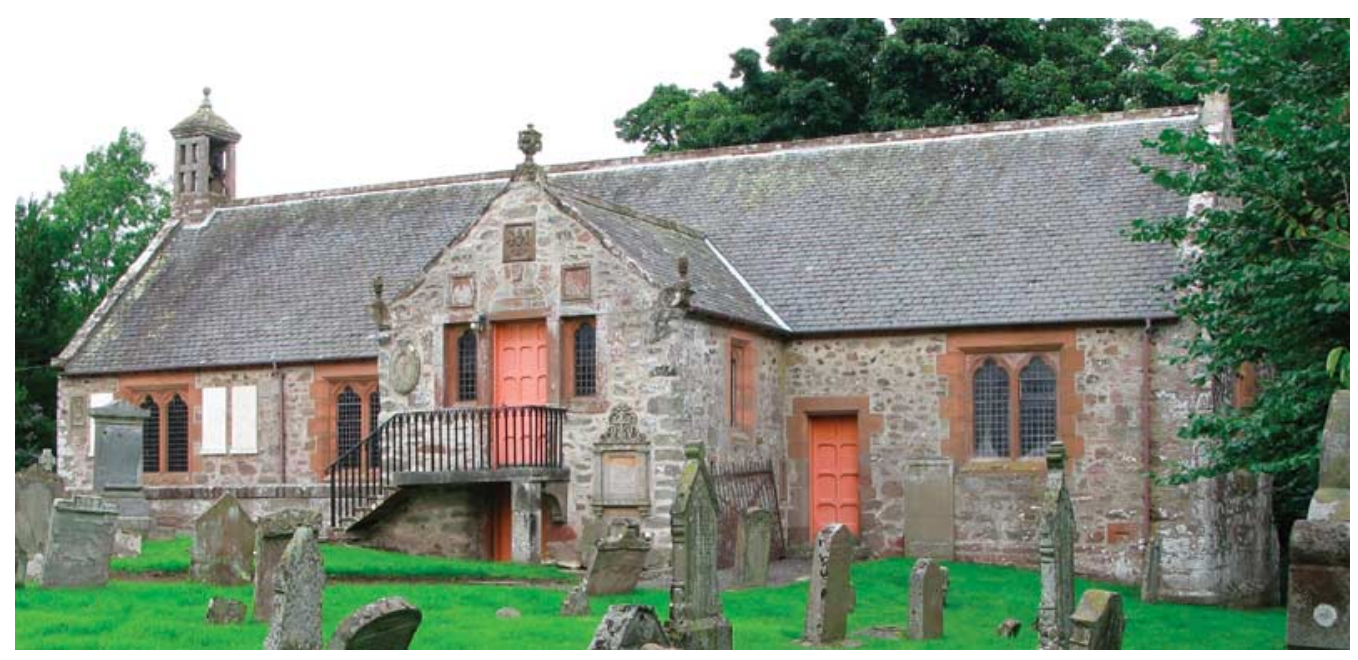

Fig I6. Forgandenny church from the south. The aisle projecting from the south flank may have originated as the chapel of St Katherine, which was founded in I494, but it later became the aisle of the Ruthven of Freeland family

the parish church are recorded at Alyth (see fig 20), ${ }^{40}$ Auchterhouse, ${ }^{41}$ Crieff, ${ }^{42}$ Forgandenny, ${ }^{43}$ Muthill (see fig I 7 ), ${ }^{44}$ Tealing ${ }^{45}$ and Tibbermore. ${ }^{46}$ In most cases there is no surviving charter or other documentary material relating to the endowment and construction of the chapels, but records do survive of the appointment of chaplains to the new foundation. This is the case at Forgandenny, where John Myretoun founded a chapel and chaplainry of St Katherine in I494, and at Tealing, where William Maxwell had founded the chapel of the Annunciation of the Blessed Virgin Mary in I512; at Tibbermore two chaplainries, dedicated to St Cuthbert and to Saints James the Great and Ninian, were founded by James Cuthbertson. Unfortunately, with the possible exception of Forgandenny (fig I6), any physical remains of these additional chapels have been obliterated by post-Reformation reconstruction of the parish churches.

Perhaps the only other form of pointer to the dating of building operations that need be mentioned here is that of statements passed on by later generations; although, as with Myln's attribution of the choir of Dunkeld to Bishop Sinclair, such statements have to be treated with caution. One example of this type of record that may be mentioned is Bishop Keith's assertion that Muthill church had been built by Michael Ochiltree when Dean of Dunblane (I420-9) $\cdot{ }^{47}$ If that statement has any basis in fact it could be no more than partly true, since Muthill is a highly complex composite structure; perhaps all that can be

40. Thomson I823, 44; National Archives of Scotland, GD 16/12/209.

4I. Reg Mag Sig I882, no. 8I; Donaldson I949, II, 33, 36, I67.

42. Reg Sec Sig 1908-82, I, nos I493, I659.

43. Burns 1976, 7; Dunlop 1956, 96-7.

44. Kirk et al I997, no. I286; Reg Mag Sig I883, nos 1339, 1342.

45. Reg Mag Sig I883, no. 4I.

46. Reg Mag Sig I882, no. 3357; Reg Mag Sig I883, no. I34I; Reg Sec Sig I908-82, v, no. 2020.

47. Russel I824. 
said is that it is an item of information that should be taken into account in analysing the later stages of the church's architectural history (see fig I7).

\section{The evidence for church planning}

The most complex churches were, of course, the two cathedrals, which were of broadly similar overall form, and where it was presumably the naves that were the location for parochial worship. Each of them eventually took shape with an extended aisle-less choir flanked to the north by an ancillary block to house the chapter house, sacristy and treasury. In both cases the nave had an aisle running the length of each side, and there was a single bell tower. At Dunblane that tower was an earlier structure that was absorbed asymmetrically into the south nave aisle, while at Dunkeld it was a slightly later addition tacked onto the north-west angle of the nave, the latter being a frequently chosen location for single bell towers in major Scottish churches. At Dunblane the aisled part of the building was of two storeys - arcade and clerestory - as was becoming more common for greater churches by the central decades of the thirteenth century, though it is possible the original intention had been to have three storeys. At Dunkeld (see fig I) the nave was an example of the revived interest in three-storeyed elevations - with a blind middle storey that was expressed in a number of major fifteenth-century churches in Scotland.

The modestly endowed Augustinian priory church at Inchmahome, which may have continued to serve a parochial function for a while, could not aspire to anything approaching the relative splendours of Dunblane and Dunkeld, though some of its details do seem to have been inspired by the former. Nevertheless, in its final form it had an aisle-less choir with a north sacristy, and a nave with a single aisle on the north side of the church, the side away from the cloister, together with a rather eccentrically inserted tower in the western bay of that aisle.

As for churches built to serve a purely parochial function, no four-compartment plans are known with certainty to have existed within the study area. At Bunkle, however, one of the diocese of Dunkeld's outliers south of the Forth (see fig II), there is the only survivor of an eastern termination in the form of a rounded apse, which is presumably of early twelfth-century date; it cannot be ruled out that this was one element in a four-part plan, like those at Dalmeny or Tyninghame outside the study area. Three-compartment plans, consisting of a rectangular chancel, a slightly wider and longer rectangular nave, and a western tower, clearly existed at Dunning (see fig 2) and almost certainly at Muthill in its earlier state (fig I7), while the survival of later western towers at Aberlady and Cramond suggests that these churches were also of a scale and date consistent with that plan type.

A larger number of churches may once have had two-compartment plans than now appears, though, as with those with three-compartment plans, none has escaped extensive later modifications. Nevertheless, one certainly existed at Aberdour before the later addition of a single aisle (see fig I9), and there are reasons of varying strength for believing that this was the original plan at a number of other churches. ${ }^{48}$ Chancel arches, which presumably invariably marked the junction of chancel and nave in three- and two-cell churches, have generally been swept away as part of the post-Reformation effort to create unified spaces more appropriate for use as preaching halls. The only surviving examples, apart from those at Dunblane and Dunkeld cathedrals, are now at Aberdour, Auchterhouse (fig I8) and

48. At Abernethy, Alyth, Auchterhouse, Caputh, Crieff, Dull, Kilmadock, Kincardine, Lecropt, Preston and Tibbermore, and perhaps also at Rosyth. 


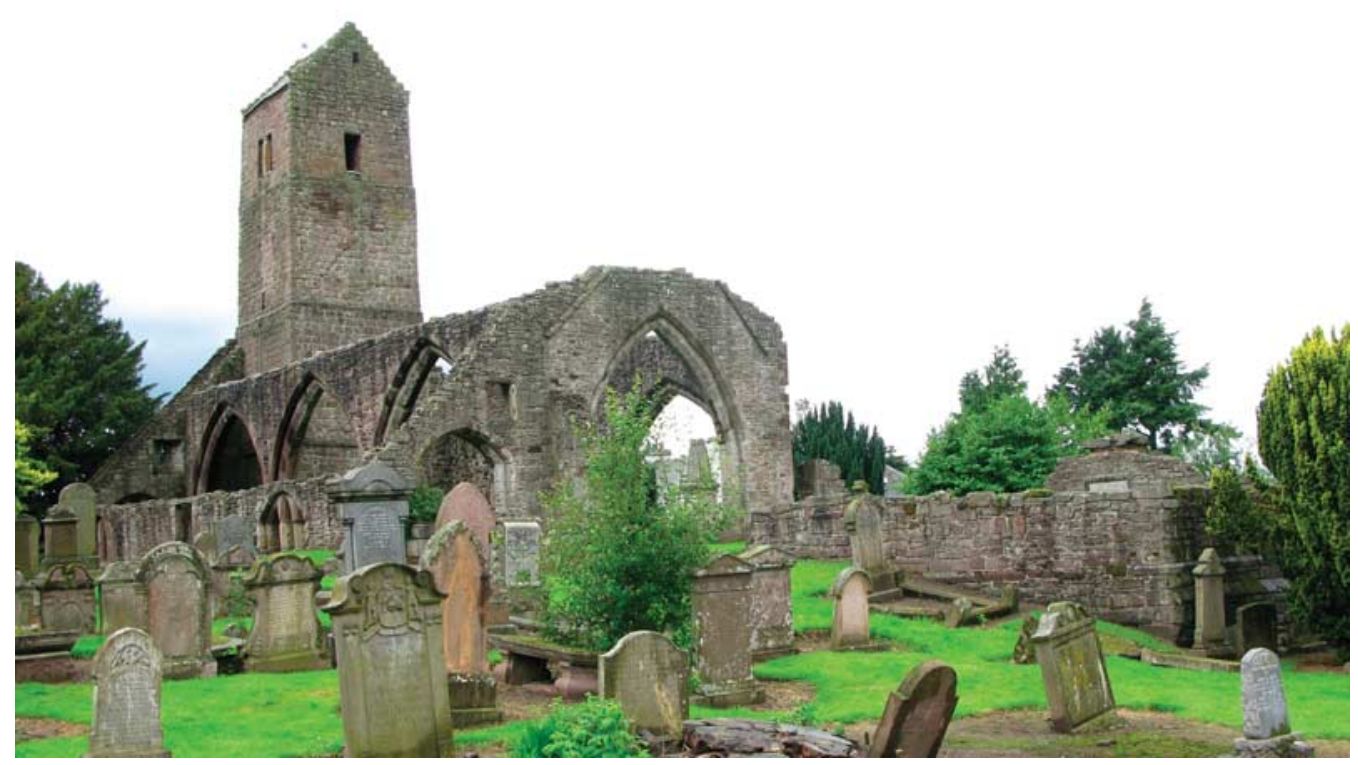

Fig 17. Muthill church from the south east. This was one of the most ambitious non-cathedral parish churches in the study area; the nave aisles were a secondary addition to a three-compartment plan

Muthill (see fig 17), though a simple arch at Preston could be in the location of a medieval predecessor, and there are traces of a wall that could have been associated with a chancel arch at Rosyth. There is also an apse arch at Bunkle of very simple form (see fig II).

In a small number of cases, churches were enlarged by the addition of aisles, either in the more commonly understood sense of the word as a longitudinal space separated from the nave by an arcade, or in the common Scottish sense of a unicameral lateral projection. Such additions were presumably made in order to provide additional space for altars, as well as to accommodate the numbers of lay folk who wished to participate in parochial worship. At Aberdour a single longitudinal aisle was added on the south side of the nave (fig I9). At the considerably larger church of Alyth, where one arcade has survived the demolition of the rest of the building (fig 20), descriptions establish that there was an aisle down each flank of the nave, ${ }^{49}$ with references to differences of detailing indicating that the aisles had almost certainly been added on separate occasions. ${ }^{50}$ At Muthill, while the two arcades are attached to the retained tower in differing ways (see fig I2), it appears more likely that the pair of aisles was added in a single campaign. At both Aberdour and Muthill the nave roofs swept across central vessel and aisles without break, and with no clerestory to introduce direct light into the central vessel. The relationship of the north wall of the chancel to the surviving arcade at Alyth suggests that is also likely to have been the case there.

The addition of laterally projecting rectangular aisles was a relatively common way of augmenting churches in Scotland, though, in the absence of documentation, it can sometimes be difficult to be certain if they had been built as chapels in the Middle Ages, or if they

49. Macfarlane 1906, I, I09.

50. New Statistical Account of Scotland 1834-45, 8, I88-9. 


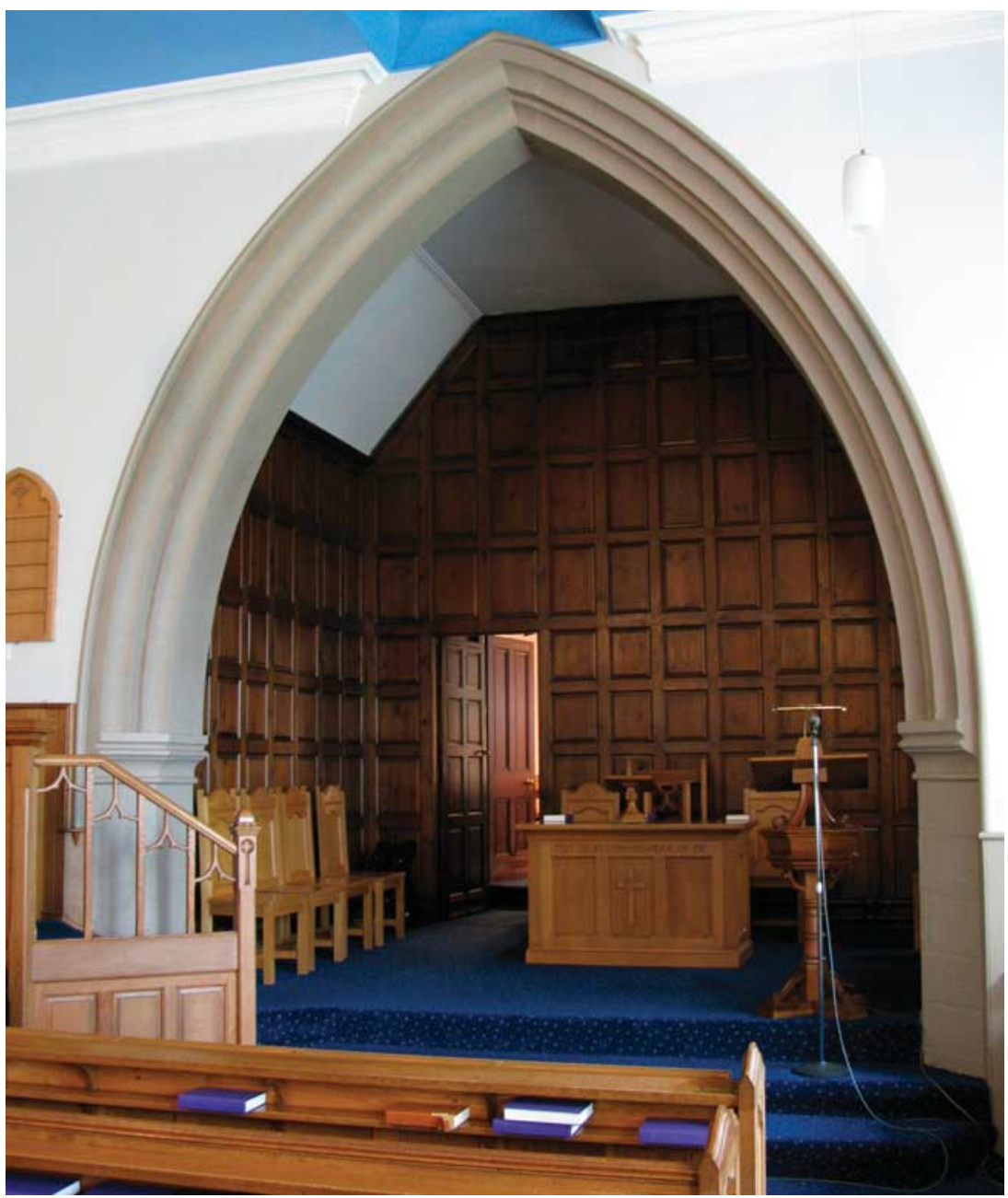

Fig I8. Auchterhouse church: the chancel arch. The chancel had been adapted as a laird's aisle in I630, but was restored as a sanctuary in I9IO

were added after the Reformation as lairds' aisles. Francis Grose's engraving of Abernethy, which is dated to $\mathbf{1 7 9 0}$, may be interpreted as showing that it had a rectangular lateral projection towards the west end of the chancel's south wall, and in that position it may well have been a medieval chapel (fig 2I). ${ }^{5 \mathrm{I}}$ There is a rectangular projection in a related position at the rectangular church of Culross. In both those cases the crow-stepped gables, and in the case of Culross the rectangular mullioned windows, point to a date no earlier than the late fifteenth or sixteenth centuries. In the case of Culross, however, it is significant that the windows are only in the south and west walls, since one reason for the absence of a window in the east wall of late medieval chapels is generally assumed to be that an altar and its retable were to be placed there (fig 22). In both those cases, therefore, it must be seen as a clear 


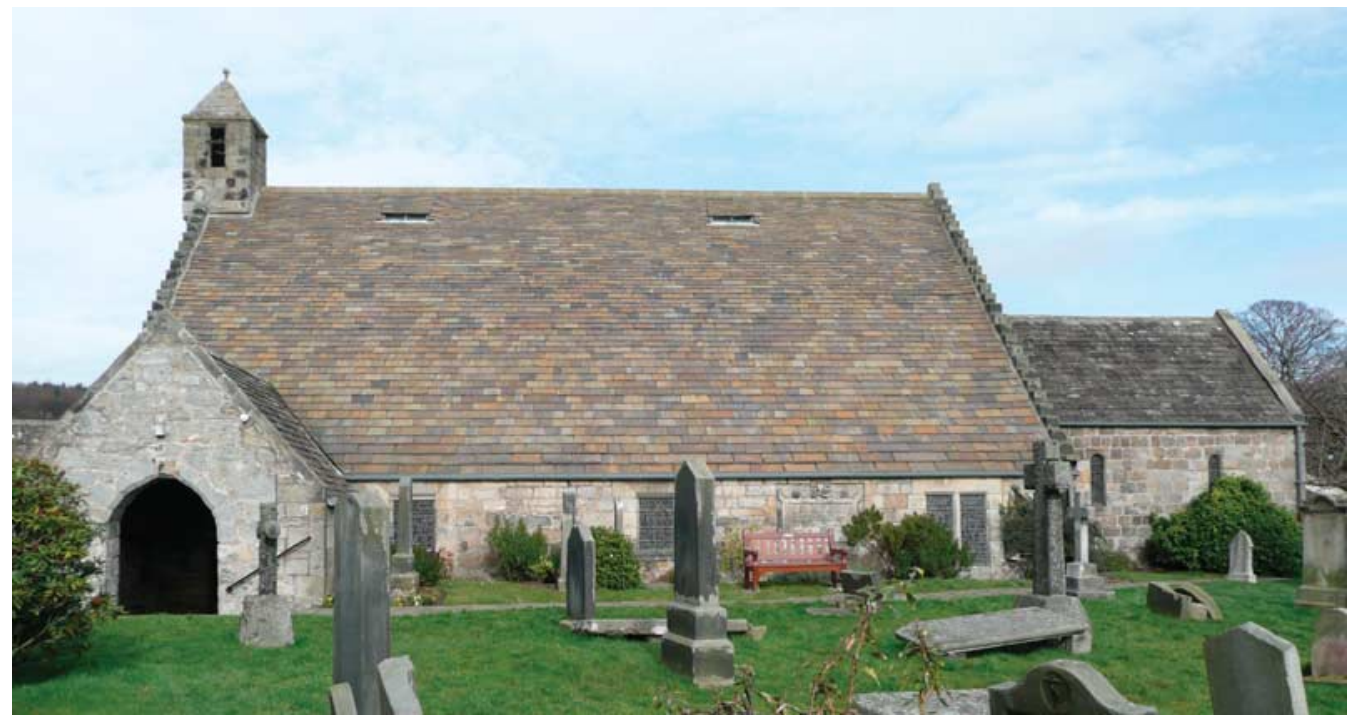

Fig 19. Aberdour church from the south. The later south aisle is covered by a continuation of the nave roof

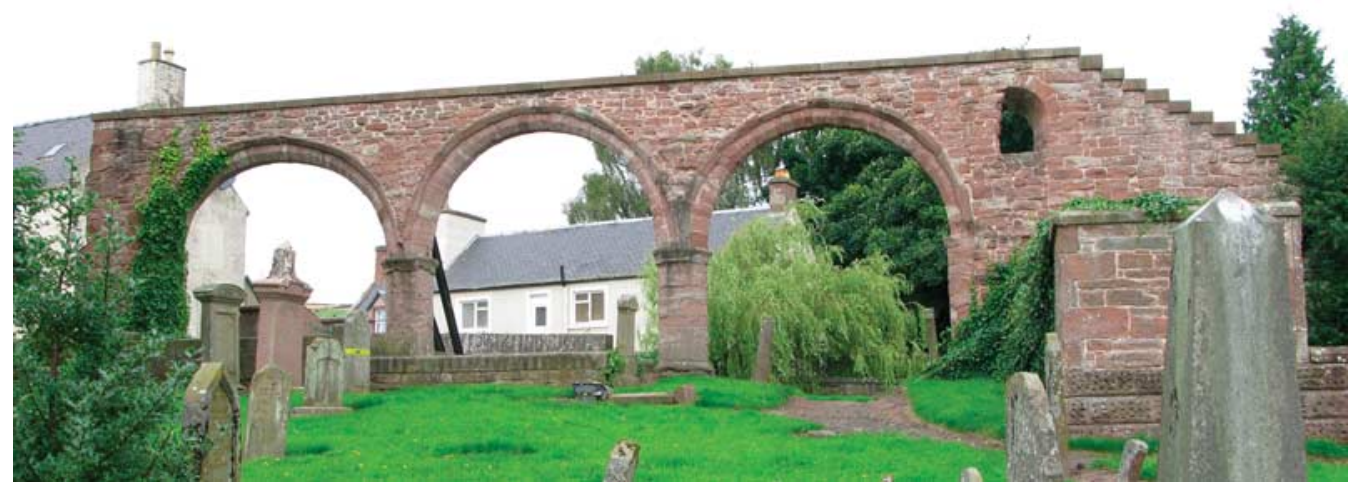

Fig 20. Alyth church: the surviving late medieval north arcade from the south. This was preserved after a new church was built in 1836 because it was believed to be 'in the Saxon style of architecture'

possibility that the projections had been built before the Reformation as chapels, and that they had then been retained for use as lairds' aisles. At Forgandenny, it must be thought likely that the substantial laird's aisle which projects from the south side of the present parish church perpetuates the chapel of St Katherine, which itself possibly incorporated the earlier chapel of St Mary 'within the cemetery' (see fig I6). ${ }^{52}$

52. At Alyth, Forgandenny, Leslie and Tibbermore reference to buildings as standing 'in the cemetery' of the church may indicate that they were projections from the core building and, as discussed above, consequently deemed separate from it rather than being wholly detached structures. 


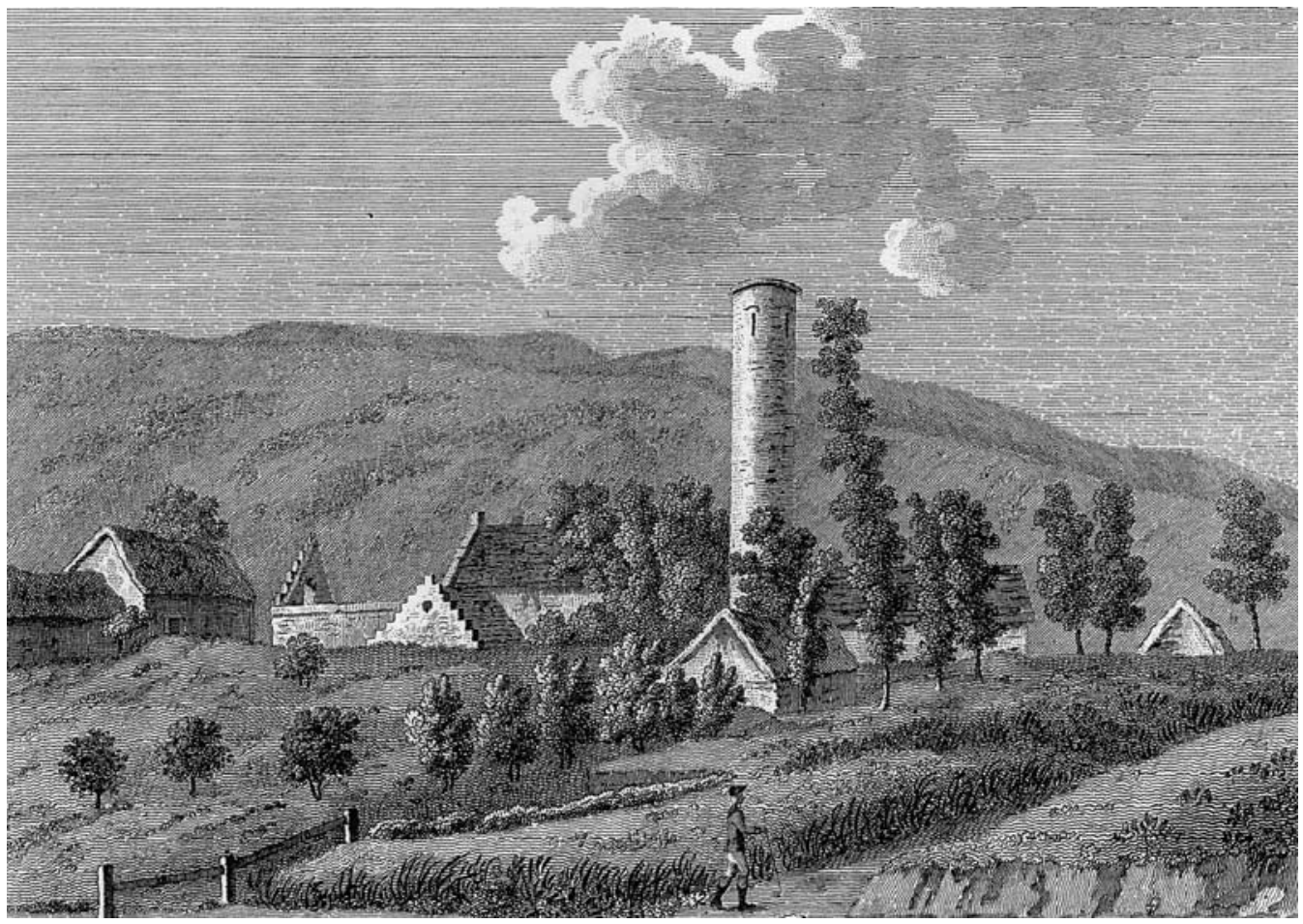

Fig 2I. Abernethy church, as depicted by Francis Grose in 1790

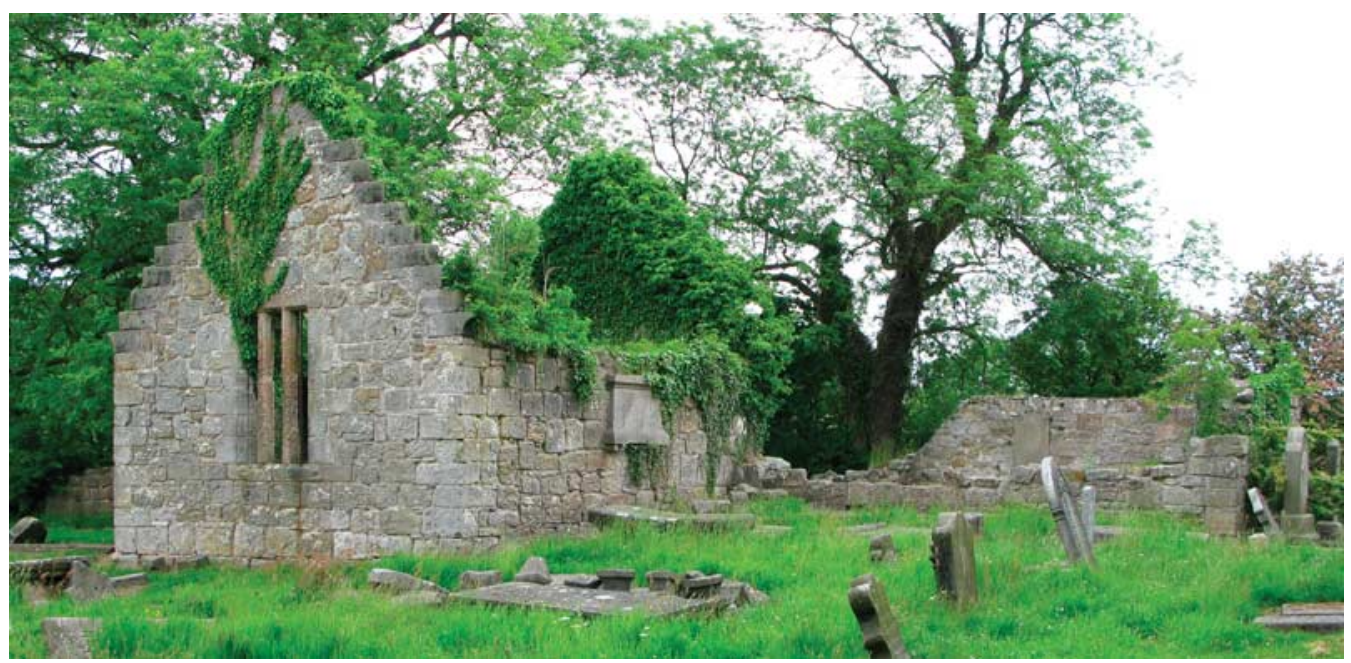

Fig 22. Culross church from the south east. The laterally projecting aisle is to the left of this view and the chancel to the right

By the later Middle Ages churches of the more complex plan types discussed above were exceptional, and from the thirteenth century most churches were set out to an unaugmented rectangular plan, as at Dalgety (see fig 4 ). In churches of this simple plan 
type, the internal division between chancel and nave would almost certainly have been marked by a timber screen; but, with the possible exception of Rosyth in its final form, there would be no chancel arch at the junction of the two parts. Rectangular churches could be of widely varying scale, depending presumably on both the parochial population and the wealth of those responsible for their construction. However, in attempting to assess the evidence they provide, account must be taken of the range of ways discussed above in which they have all been adapted in varying degrees in the course of the four and a half centuries since the Reformation. To obtain anything approaching an accurate idea of the gamut of possible sizes and relative proportions of rectangular churches, it would be necessary to have more complete information on all of the buildings of this type in the two dioceses than we now have. Nevertheless, if we take account of all of those churches where we can be reasonably confident of the breadth and length, the average dimensions have been found to be 19.34 by $7.19 \mathrm{~m}$ ( 63.5 by $23.6 \mathrm{ft}$ ), giving proportions of $\mathrm{I}: 2.69$.

\section{The architectural evidence}

The near-universal building material for churches in the study area was sandstone. ${ }^{53}$ Except at Dunkeld, where the soft blue-green or pink stone easily lent itself to precisely cut ashlar blocks (see fig I), the stone was employed chiefly as rubble, the characteristics of which vary greatly according to the nature of the stone and the local building traditions. It is only in a number of churches that are likely to be of twelfth- and early thirteenth-century date, where the stone was worked into large squared blocks, that the masonry character may be taken as some indication of date, as in parts of Abercorn, Aberdour (see fig I9), Auchtertool (see fig 9), Forgandenny (see fig I6), Muthill (see fig I7) and Rosyth. The colours vary widely across the area: there are deep purples (Dunblane - see fig 25), reds (Ecclesiamagirdle and Preston), pinks (Aberuthven, Fowlis Wester - see fig 7, and Muthill - see fig I7), buffs and browns (Bunkle - see fig II, Crombie, Culross - see fig 22, and Preston - see fig I2), blue-green (Dunkeld - see fig I) and greys (Blair, Cargill, Dull, Lude, Strowan and Tullibody). Except at the two cathedrals, relatively little carved or moulded detail of diagnostic value has survived the succession of changes that most churches have undergone, though it may be suspected that at many - perhaps most - churches the amount of carved or moulded work was relatively limited. For our present purposes the most obvious consequence of this is that very few churches present features that would help us to date them in the absence of documentation.

The most lavishly finished buildings within the area were, of course, the major cathedrals and religious houses. Dunblane and Dunkeld cathedrals between them embody some of the most significant Scottish ecclesiastical architecture of the thirteenth and fifteenth centuries. There is also fine smaller scale work of the thirteenth century at Inchmahome, while the few surviving ex situ fragments at Coupar Angus make clear that the Cistercian abbey church there must have been a building of considerable quality.

In the course of the study attention was paid to the ways in which the major churches might have acted as models for the dissemination of architectural ideas. In general, however, there was little evidence to establish that this happened in more than a small number of cases, presumably largely for economic reasons, though it may in part be attributable to the fact that the post-Reformation losses of architectural detailing at the

53. A useful introduction to the building materials in the area is to be found in Gifford and Walker 2002, I-9, and Gifford 2007, I-4. 


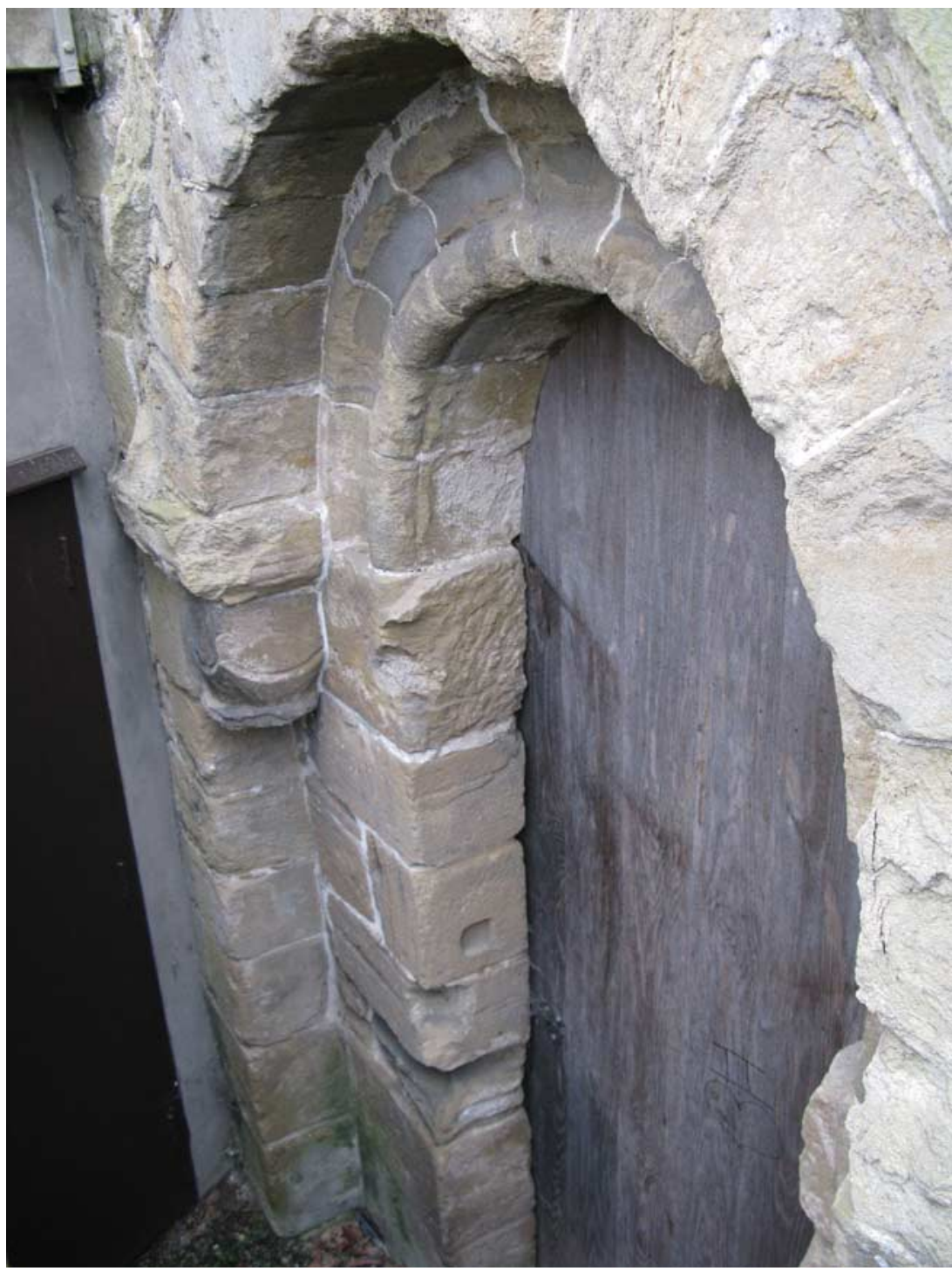

Fig 23. Dunning church: north doorway. This doorway is usually largely concealed by the forestair to the galleries in the nave and north aisle, and this view was taken when it was exposed for a period

parish churches have been so great. As has been said, we know that one of the bishops of Dunkeld employed a named wright, John Fendour, who is thought to have been one of the leading figures in his field, suggesting that even small churches might once have contained work by high-calibre craftsmen. On the architectural evidence it seems that masons who had worked at Dunblane in the mid-twelfth century may have moved on to work at Dunning, where the north door (fig 23) is broadly comparable with the door at the base of Dunblane's tower (fig 24). The overall design of Dunblane's tower (fig 25) may have been looked to for inspiration in building the towers at both Dunning and Muthill 


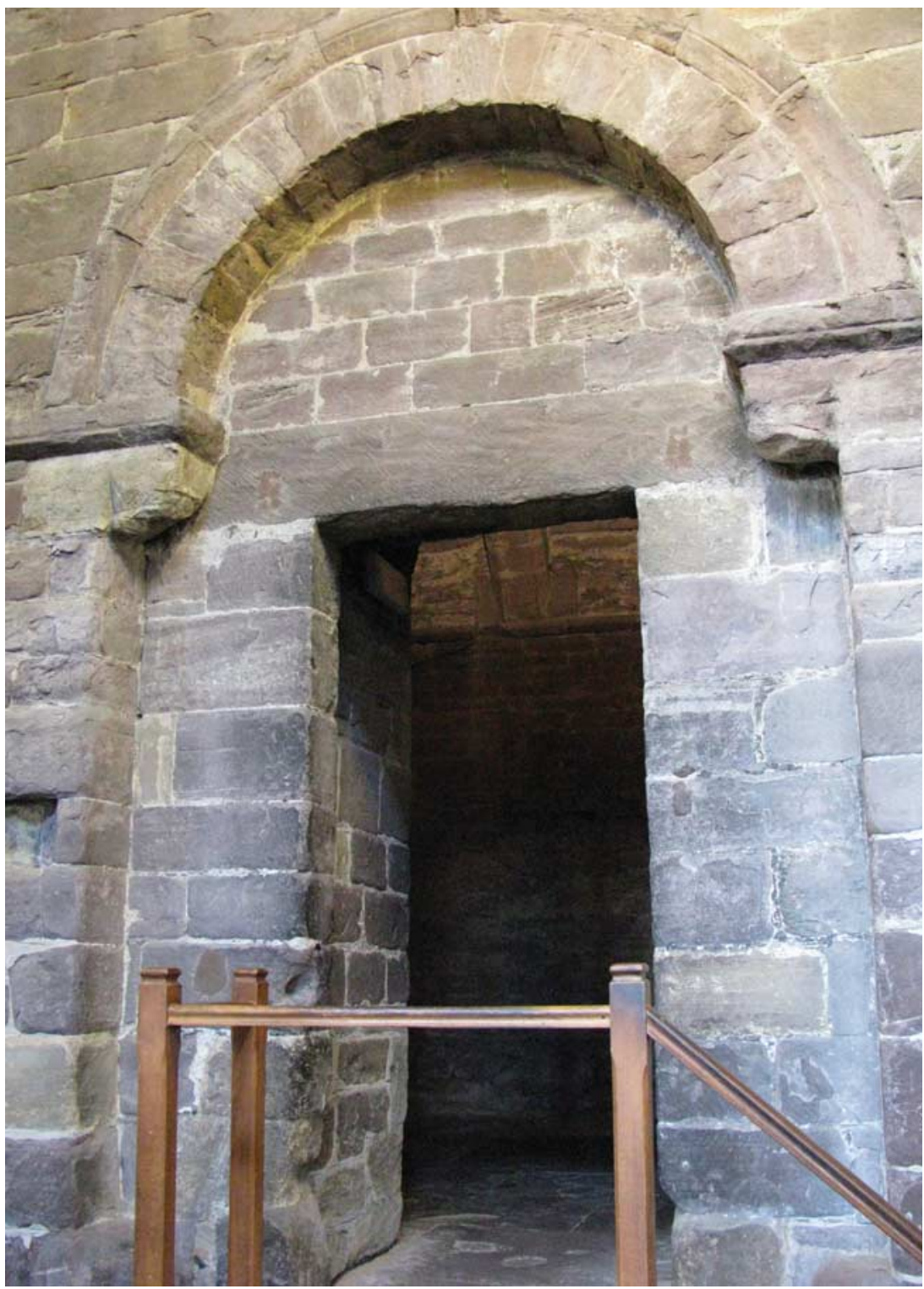

Fig 24. Dunblane cathedral: the doorway in the north face of the tower

(see figs 2 and I7), while at the latter the continuing architectural authority of Dunblane into the later Middle Ages may be evident in the unusual form of the windows of the south nave aisle.

Elsewhere there is less certainty as to how far the use of certain details can be attributed to the influence of the major churches, though here account must be taken of the fact that much earlier work has been lost at the cathedrals themselves. Apart from Dunblane's tower, both cathedrals are now predominantly buildings of the thirteenth or fifteenth centuries. But in each case the present buildings must have replaced earlier ones, 


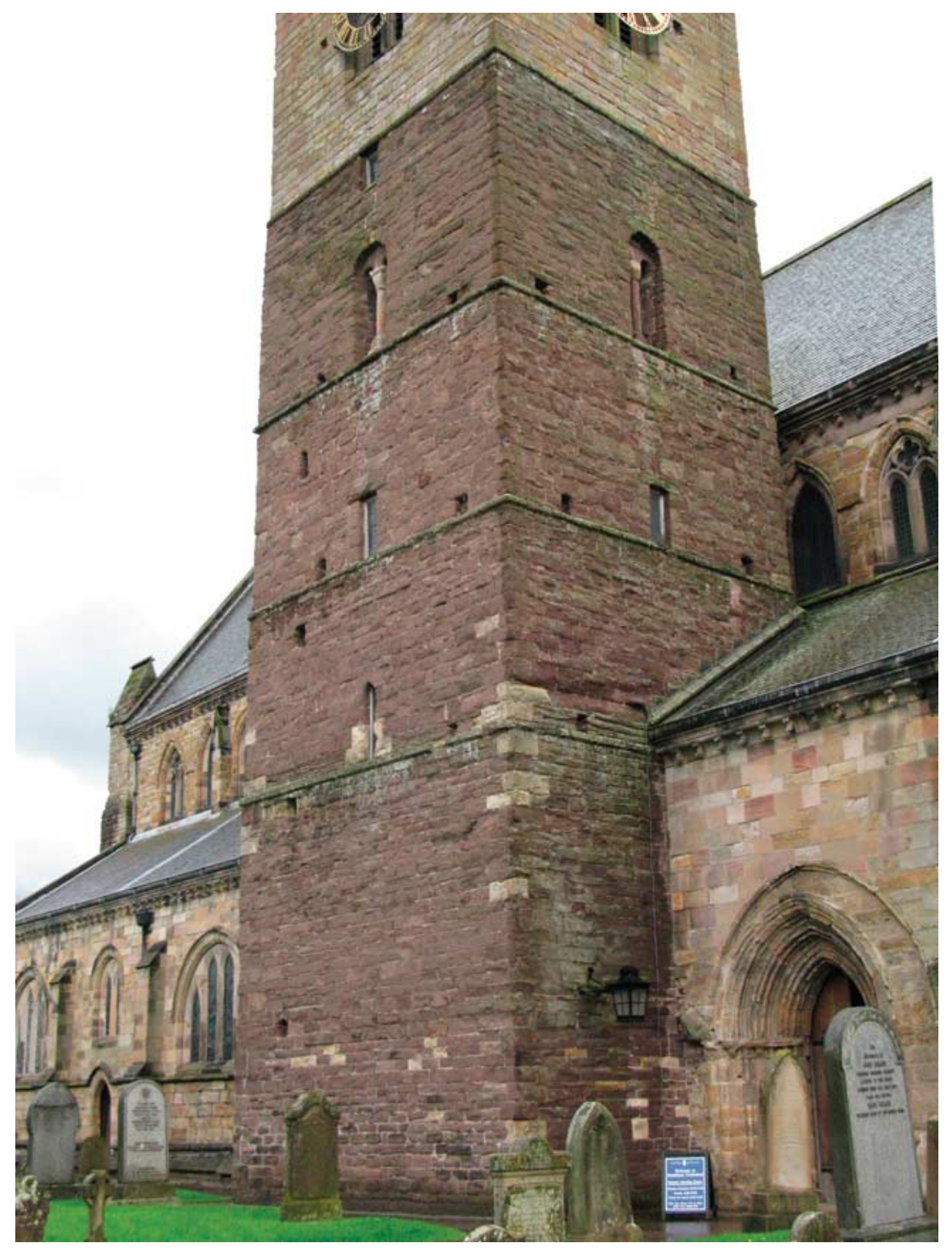

Fig 25. Dunblane cathedral: the twelfth-century lower stages of the tower

and at Dunblane there are some chevron-moulded voussoirs to remind us that there was once a highly finished mid-twelfth-century building there. Could there have been something in that building to inspire work of which we no longer have more than fragments at Abercorn and Forgandenny, for example? At the former there is a doorway that, although not of the highest quality, is of interest on account of its tympanum, which is decorated with a somewhat irregular diamond pattern (fig 26). At Forgandenny is what appears to be a length of Romanesque chevron-decorated hoodmoulding, presumably from a doorway, which has been re-set in the south wall.

For the few other surviving carved or moulded fragments, little can now be said about the models from which they may have taken their lead. Doorways of the later twelfth and 


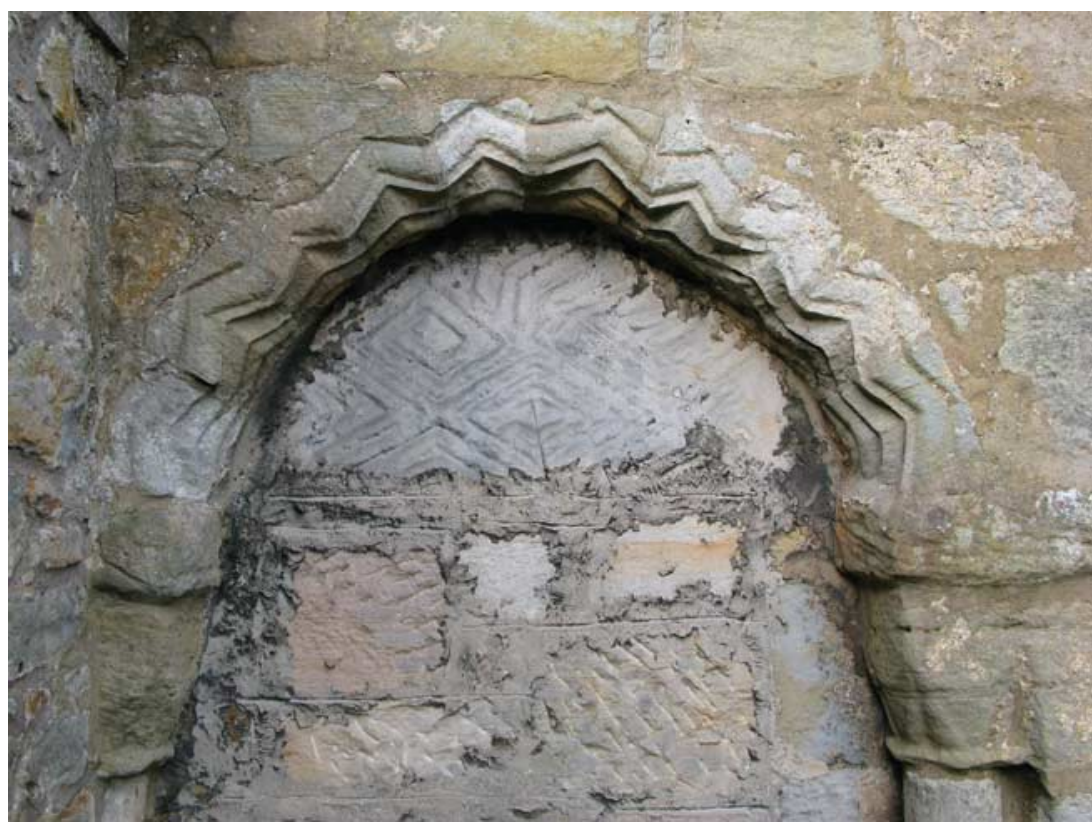

Fig 26. Abercorn church: the tympanum of the south nave doorway

earlier thirteenth centuries are represented in ex situ fragments at Clunie and Leny, those at the former having been re-set in a modern composite doorway that has waterleaf caps and a segmental dogtooth-decorated arch (fig 27). Leny has retained a capital with what appears to be a depiction of the crucified Christ carved on its bell (fig 28). Doorways of a variety of later dates are to be seen at Auchterhouse, Bendochy, Dalgety and Tullibody. Those at Auchterhouse are of particular interest since in their present form they evidently represent the post-medieval re-use of late medieval work interpolated with new elements (fig 29). There is much to suggest that Auchterhouse was an unusually fine building (see also fig I8), and it is one of the few rural parish churches in the study area where there are fragments of one or more notable traceried windows. The quality of the work here may point to the resources available to the lay patrons of the parish church in the fifteenth and sixteenth centuries, the Ogilvy lords of Airlie and Lintrathen and the Stewart earls of Buchan. How comparable levels of patronage were expressed at other parish churches in the study area is perhaps reflected in the carved fragments that survive at, for example, Tealing, where a carving of Christ in Majesty has been re-set in a wall adjacent to the churchyard entrance. Other architectural fragments are to be seen out of their designed context at Bunkle, Culross, Muckairn, Strowan, Tillicoultry and perhaps at Trinity Gask, though it must be conceded that in none of those cases do the fragments add significantly to our understanding of the churches of which they once formed a part.

\section{Liturgical fixtures and furnishings and monuments}

The fixtures and furnishings associated with the celebration of the liturgy were a principal target of the first generation of reformers, and the losses have consequently been great. 


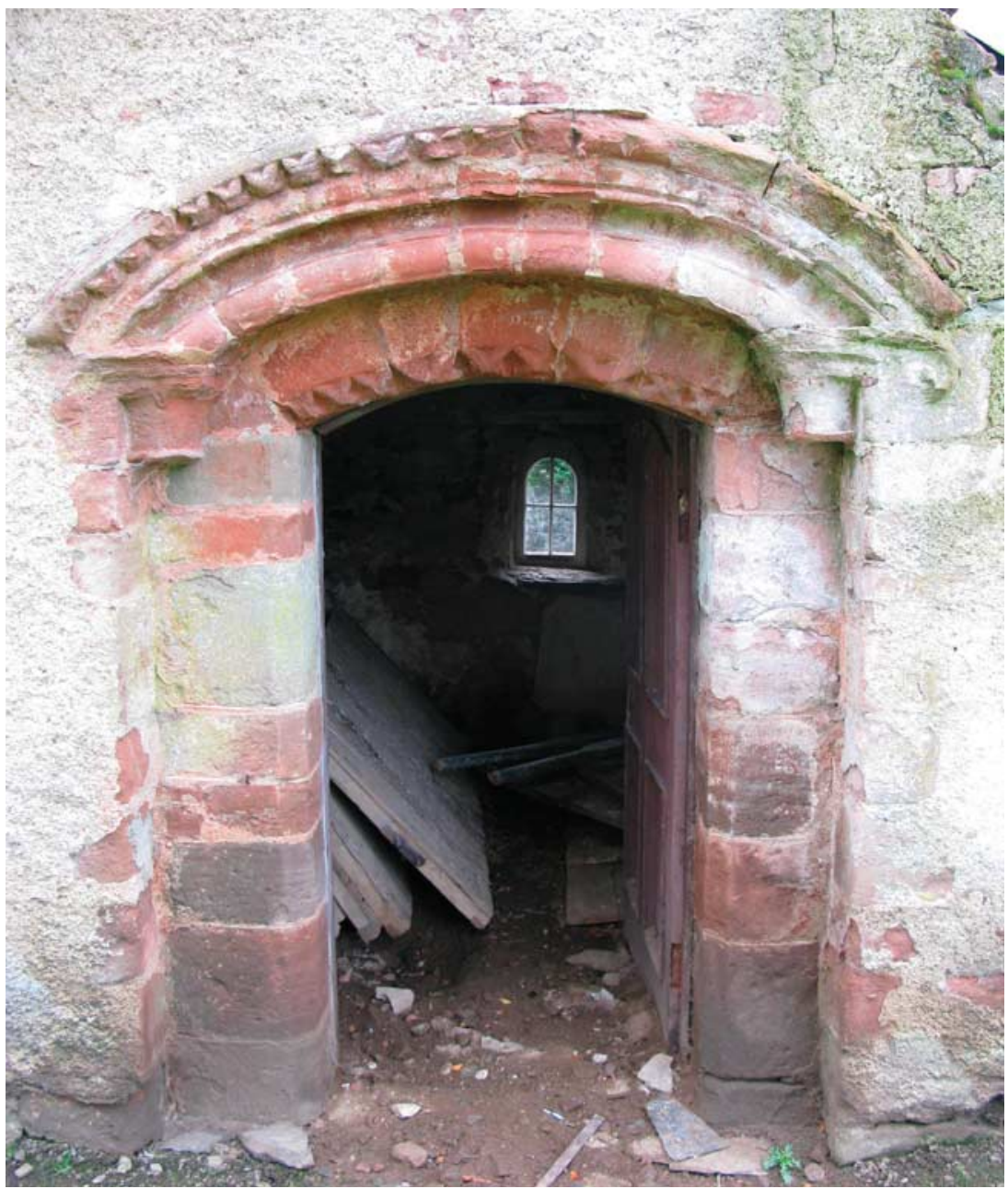

Fig 27. Clunie: fragments built into a doorway in the churchyard

If we start by considering the evidence for the location of altars, at Dunblane there is what appears to be a twelfth-century arched altar recess in the lowest storey of the tower. At Dunkeld there are indications of the location of the altar in Bishop Cardeny's chapel at the east end of the south nave aisle, in the form of chases in the wall that were presumably intended for the attachment of a retable (fig 30). Adjacent to this wall is a piscina recess, confirming the erstwhile proximity of an altar, and there are other piscinae at Dalgety, Dunblane, Dunkeld, Inchmahome and Preston, amongst others. The most common feature associated with an altar that has come down to us is the aumbry, which is usually nothing more than a rectangular recess, albeit sometimes with a rebate for a door frame. When such simple aumbries are in the north wall, or in the east wall as at Crombie and Fowlis Wester, it is possible that they served the exalted function of a Sacrament House, where the consecrated host was reserved for adoration. In such cases the sacred function of the recess may once have been emphasized by long-lost painted or carved timber surrounds. More richly decorated stone Sacrament Houses, of the kinds that have 


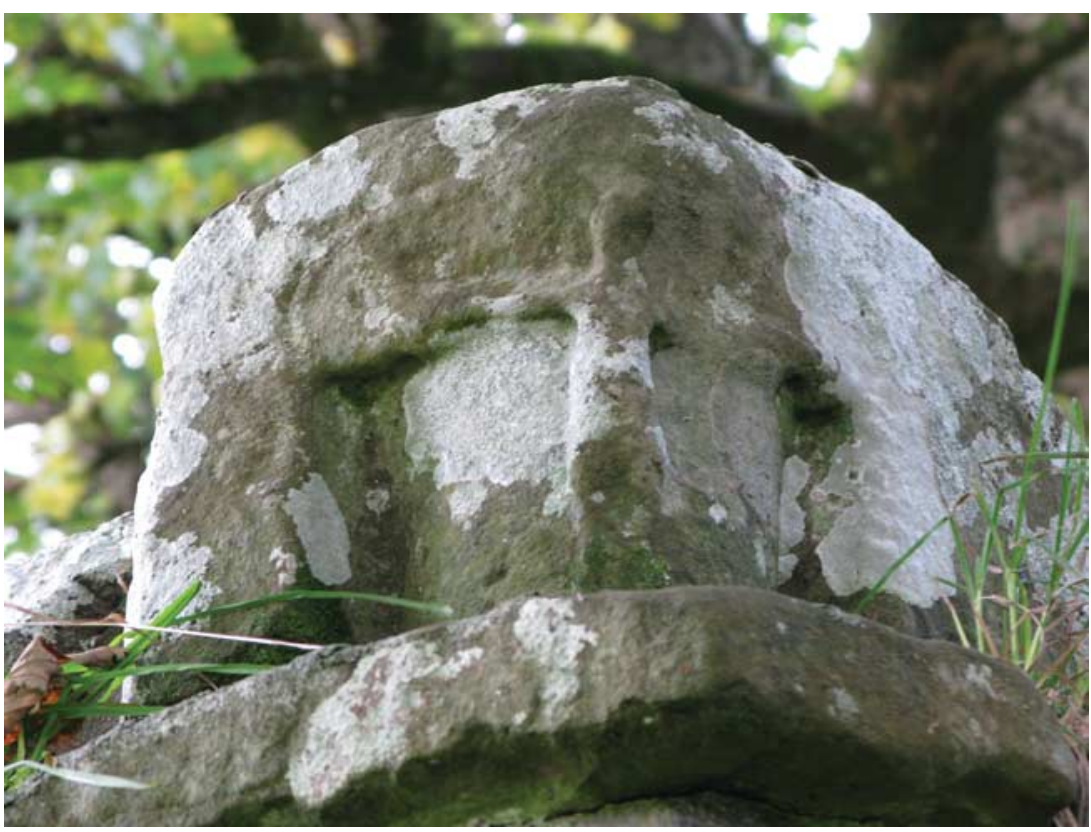

Fig 28. Leny: an ex situ capital carved with what appears to be the crucified Christ

survived especially well in the north east of the country, ${ }^{54}$ appear to have received short shrift within the study area. Fragments identifiable as having come from Sacrament Houses at Bendochy and Tealing had apparently been removed, desecrated and buried after the Reformation; it was only once confessional antipathy had been at least partly superseded by antiquarian interest that they were returned to their churches in the nineteenth century. It is particularly unfortunate that the fine fragment at Tealing is within a church that is closed and no longer accessible.

Sedilia designed with any sort of microarchitectural detailing were unlikely to be found in any but the most important churches, and the only surviving examples are at Dunkeld cathedral and Inchmahome priory, though it is recorded that a fragment of one existed at Muthill. Timber choirstalls are also unlikely to have been provided outside the most splendidly endowed and staffed churches. The finest examples that have survived are those at Dunblane, though it is possible that a series of timber arches with richly traceried spandrels from Muthill church, now in the National Museum in Edinburgh, were from furnishings, such as stalls. It may also be wondered if the stone arcading that runs along the north wall at Dunkeld was intended to serve as seating for the cathedral clergy as well as being a fine decorative feature.

Needless to say, none of the timber screens that would once have enclosed parts of the churches have survived in place, though at Dunblane cathedral the backs of six of the stalls evidently served as the two halves of the chancel screen, and the timber arch that spanned the choir entrance between them is preserved in the cathedral museum. At Dunkeld cathedral slots cut into the arcade piers may be a reminder of the location of the 


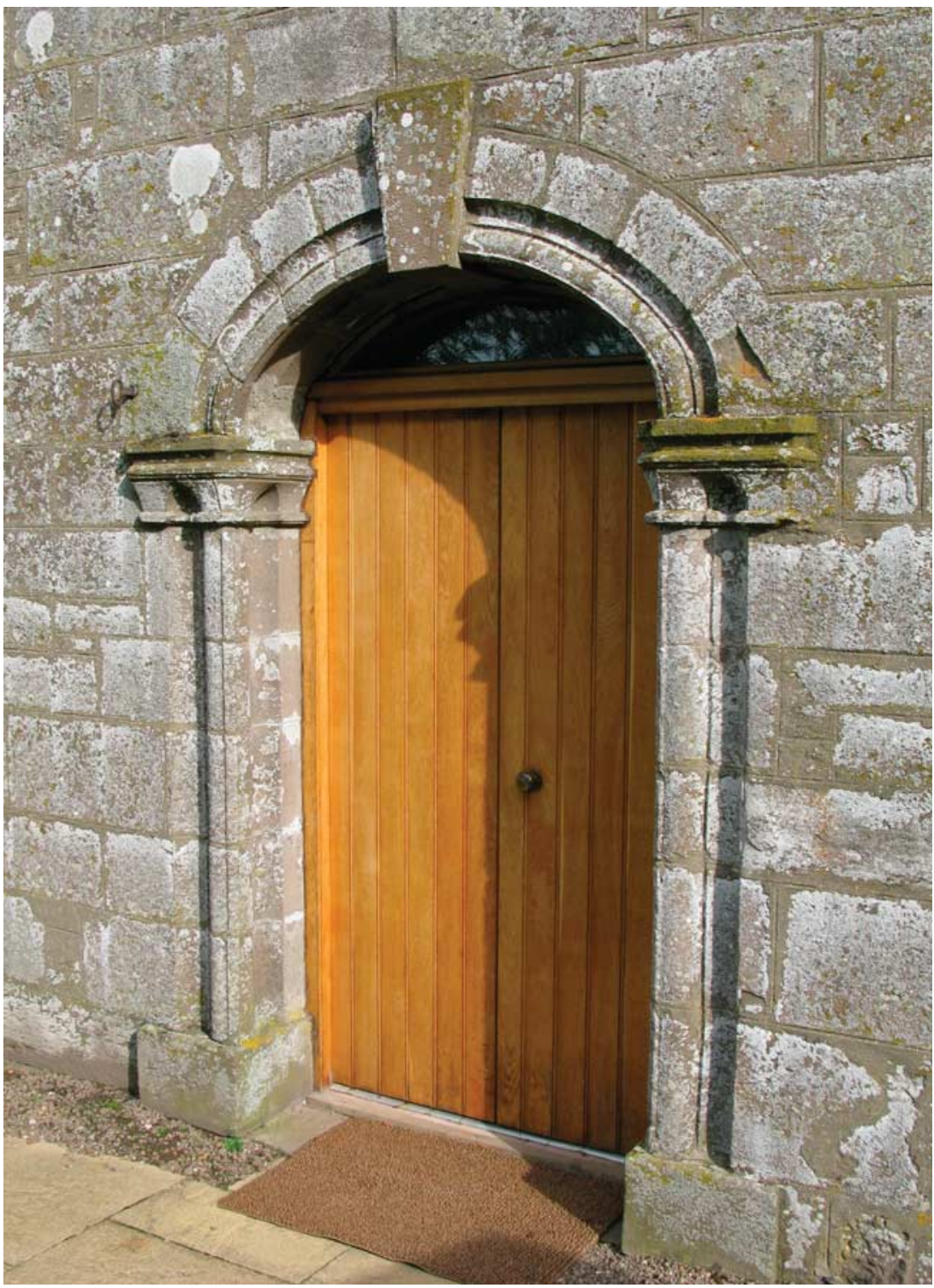

Fig 29. Auchterhouse church: south nave doorway. This appears to incorporate late medieval jamb and arch mouldings within a doorway of 1775

parclose screens around Bishop Cardeny's chapel in the south aisle. Dunkeld also has horizontal slots above the east nave arcade responds that were presumably cut as the seating for the rood beam (see fig 30), while above the chancel arch at Dunblane there are small pockets that could have been for the diagonal braces of a cantilevered rood loft. At a parochial level, Tullibody has traces of a high window in the south wall of the kind that was provided to light the rood loft at a number of mendicant and collegiate churches.

Of the nave furnishings, there is evidence of holy water stoups at Aberdour, Rosyth and Tullibody. Several churches have retained fonts, or what have come to be regarded 


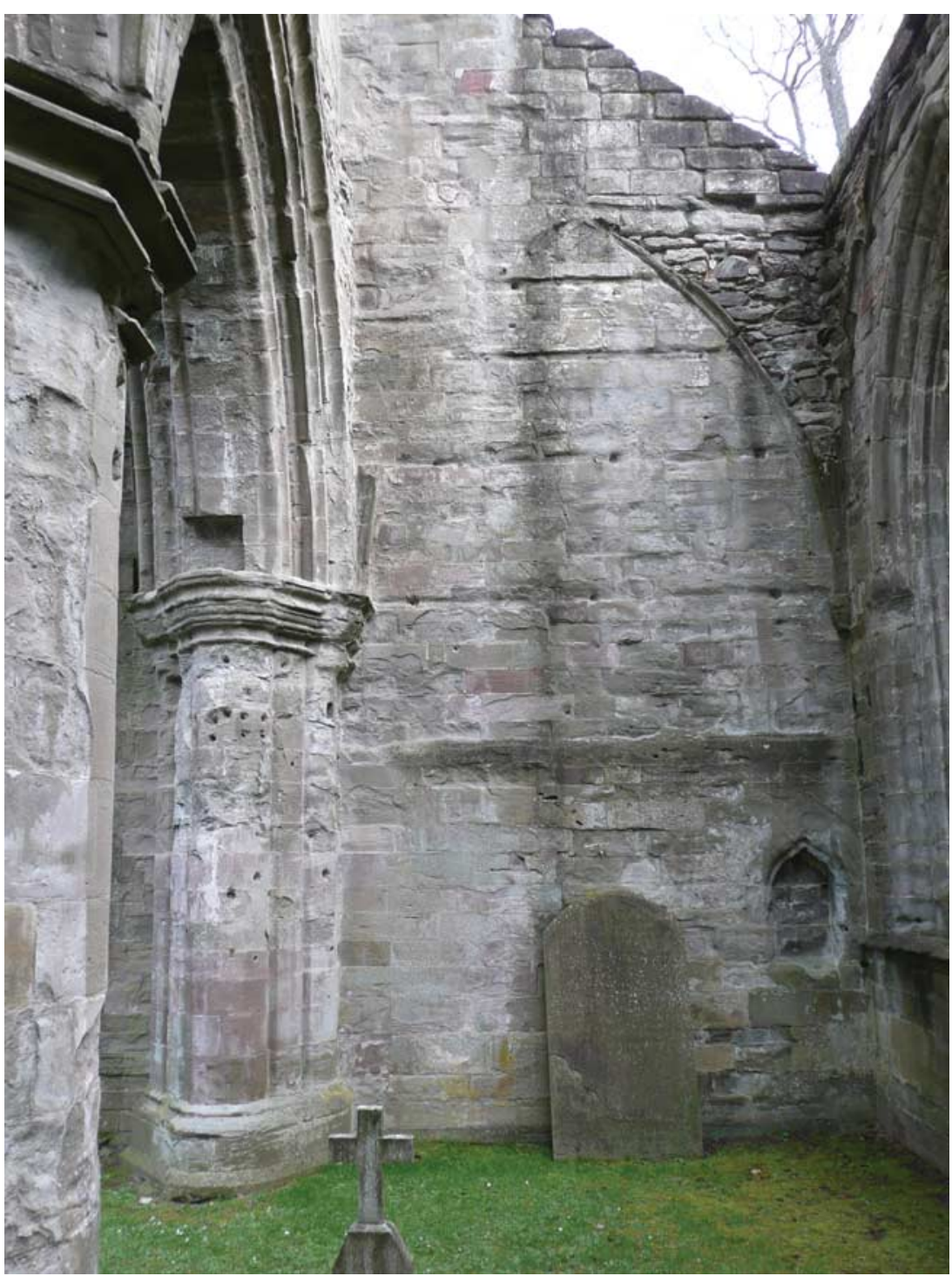

Fig 30. Dunkeld cathedral: east wall of the south nave aisle. The horizontal chases in the wall are perhaps for the fixings of an altar retable; a piscina is seen to the right

as fonts. ${ }^{55}$ However, since stone fonts were almost invariably turned out of their churches at the Reformation, it is by no means always certain that they originated in the buildings in which they have now been relocated. The finest font bowl within our study area is at Meigle, where the eight panels are decorated with low-relief scenes of the Crucifixion and Resurrection, together with depictions of the instruments of the Passion (fig 3I). A description suggests that the font at Auchterhouse may have been of similarly high quality,

55. For a general survey of fonts in Scotland see Walker i886-7. 


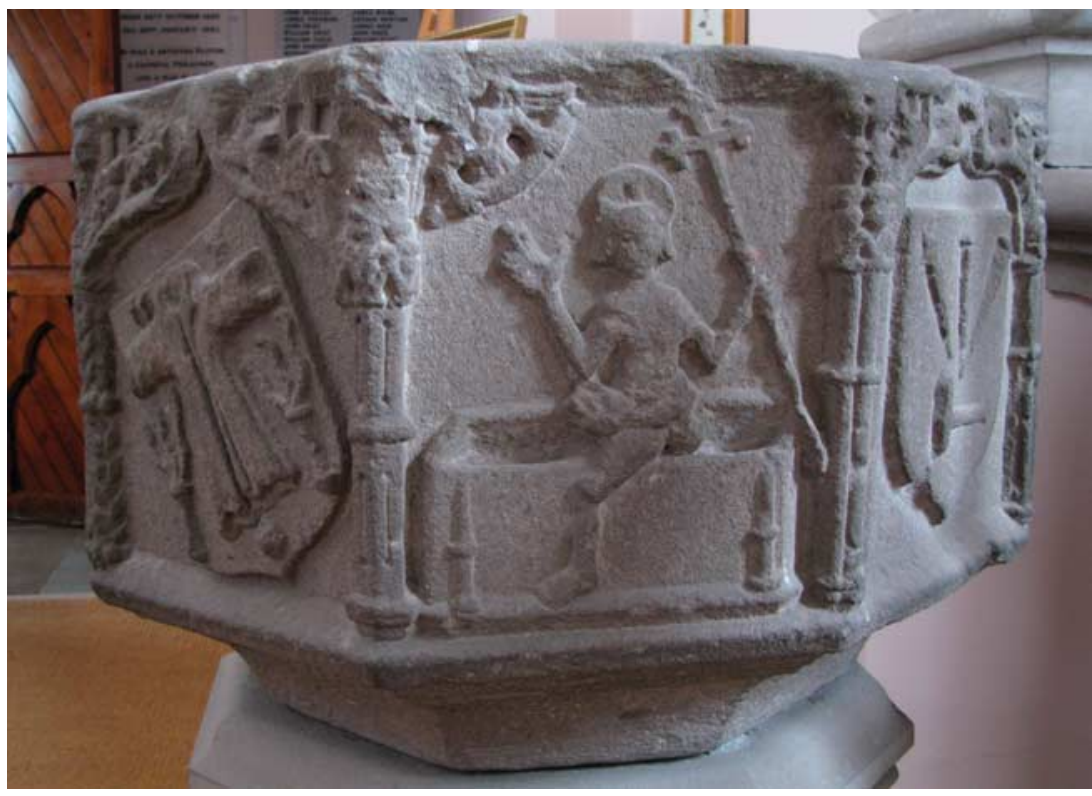

Fig 31. Meigle church font bowl, showing faces on which the Resurrection and the Instruments of the Passion are depicted

though only its base now survives. ${ }^{56}$ Simpler fonts are to be seen at Aberdour, Blair, Kilbryde and Forteviot, while at Madderty the font basin has been cut in half and mounted on the gate piers at the entrance to the churchyard. Perhaps a little perversely, with the enthusiasm for returning fonts to churches that came with growing antiquarian interest in the nineteenth and twentieth centuries, there appear to be a number of cases of domestic mortars being introduced into churches on the mistaken assumption that they were fonts. This is evidently the case at Ardeonaig, Balquhidder, Dull, Fortingall, Killin and Strathfillan; some of these are quite carefully worked, but without the drain that would be expected in a font, while others are little more than boulders into which a basin has been hollowed.

A number of types of funerary monument are to be seen across the study area. Coupar Angus, Dunblane, Dunkeld and Inchmahome have preserved full-scale effigies of either ecclesiastics or of some of the greater magnates and their ladies, while a weathered pair of secular effigies at Muthill was probably once of higher quality than its present decayed state might suggest. At Dunkeld the canopied tomb in the south-east nave chapel that is the setting for the effigy of Bishop de Cardeny has also survived, while at Dunblane there is a rather simpler tomb recess in the comparable location. At Coupar Angus there is the arcaded front of a tomb chest, within which is a series of unusually finely carved figures. The study area has retained a number of incised memorial slabs. Of outstanding quality was what can be accounted on present evidence to have been the finest incised slab in Scotland, that at Aberdalgie of Sir William Oliphant, who died in 1329/30. ${ }^{57}$ Regrettably, although it is now within the church, its long exposure to the elements has resulted in the loss of much detail. Another fine slab, at Coupar Angus, is that of Abbot John Schanwell, 
who died in $1506 .{ }^{58} \mathrm{~A}$ sixteenth-century incised slab of a canon at Dunkeld is competently rendered, and is of interest for its depiction of a prebendary's costume, though it is hardly a work of the highest quality. ${ }^{59}$ Incised and decorated slabs are also to be seen at Strowan and Tealing, while at Balquhidder there is what is presumably the memorial to one of the priests of the church that is carved with what can only be described as engaging naivety. At a lesser level of artistic ambition there are examples of cross-inscribed slabs at Abercorn, Balquhidder, Blair, Culross, Dull, Dunblane and Ruthven. At Dunblane there are also matrix stones for monumental brasses.

\section{CONCLUSION}

Of the 105 sites considered, about fourteen wholly or partly roofed churches were found to have retained a significant part of their medieval appearance, ${ }^{60}$ while twenty-two ruined churches have retained a significant part of their medieval appearance. ${ }^{6 \mathrm{I}}$ In other cases it was necessary to attempt a careful evaluation of the evidence in order to assess the likelihood of medieval fabric having survived or having conditioned what is now seen. On the basis of that evaluation, it has been concluded that considerably more medieval work has come down to us than has hitherto been assumed. At a number of churches it has been possible to identify with some confidence medieval masonry that had previously been overlooked. Elsewhere it is the form of the building that points to the underlying presence of medieval fabric, with the clearest indicators of the retention of medieval work frequently being a combination of the orientation, the size and the relative proportions of the building.

It must be said, however, that in many of the latter cases none of the three indicators mentioned would provide sufficient pointers to the survival of medieval fabric if considered in isolation. So far as the orientation of the buildings is concerned, strict east-west alignment was not always possible for medieval churches where the topography of the site created insuperable difficulties; conversely, a wish for south-facing windows meant that an oriented alignment was on occasion preferred for an entirely post-Reformation church. So far as size is concerned, this was to a great extent a function of the relative wealth and population size of the parish, and, considered in isolation, it would therefore be of limited significance. Proportions, however, do appear to be of a high level of significance. The liturgical requirement in a medieval church for a spatially - if not structurally - distinct chancel to the east of a nave almost inevitably resulted in a relatively elongated plan for rectangular churches, and, as has been indicated, this was commonly in the order of $1: 2.69$. In postmedieval churches, where a principal requirement was that all of the congregation should be close to the pulpit, proportions closer to $\mathrm{r}: 2$ were evidently preferred.

In addition to those listed above, at least fourteen churches that now present an essentially post-Reformation appearance are likely to perpetuate the footprint of their

58. Greenhill 1946-8, 99-II0.

59. Greenhill I943-4, 87-9I.

6o. Abercorn, Aberdour, Aberlady, Auchterhouse, Auchtertool, Cramond, Dowally, Dunblane, Dunkeld, Dunning, Forgandenny, Fowlis Wester, Kilmaveonaig and Weem.

6I. Aberuthven, Alyth, Ardeonaig, Auchterarder, Balquhidder, Blair, Bunkle, Crombie, Culross, Dalgety, Ecclesiamagirdle, Kilmadock, Kinkell, Kippen, Lude, Muckairn, Muthill, Preston, Rosyth, Strathfillan, Strowan and Tullibody. 
medieval predecessors and may be expected to incorporate medieval fabric. ${ }^{62}$ At least twentytwo other churches are likely to be on the site of their medieval predecessors, and, in some cases, more invasive investigation might be expected to reveal that they embody medieval masonry. ${ }^{63}$ At no more than nine medieval church sites were there found to be no structural remains of any kind of medieval church building, though the general location of the church was evident from the existence of a historic graveyard. ${ }^{64}$ In only two cases - Kenmore (Inchadin) and Obney - was there serious difficulty in identifying the exact site of the parish church because there was nothing remaining above ground to indicate its location.

\section{ACKNOWLEDGEMENTS}

The authors gratefully acknowledge the generous financial assistance of the Arts and Humanities Research Council, which made this research possible. They are also most grateful to the University of St Andrews and the School of Art History within that university for acting as host to the project and for providing support of many kinds. They offer particular thanks to Birgit Plietsch, Robert Scott, Dawn Waddell and Mary Woodcock Kroble. All the figures used in this paper are the copyright of Richard Fawcett.

\section{BIBLIOGRAPHY}

Anderson, A A 1938-9. 'Scottish medieval churches still used for divine service', Trans Scottish Ecclesiological Soc, 12, I I I-I6

Bower, W 1987-98. Scotichronicon (eds D E R Watt et al), 9 vols, Aberdeen: Aberdeen University Press

Burns, C (ed) 1976. Calendar of Papal Letters to Scotland of Clement VII of Avignon, Edinburgh: Scottish History Society

Cameron, A 2005. 'East Kirk St Nicholas', Discovery and Excavation in Scotland, new ser 6, 99, Edinburgh: Council for Scottish Archaeology

Cormack, A A 1930. Teinds and Agriculture: an historical survey, London: Oxford University Press

Cowan, I B 1967. The Parishes of Medieval Scotland, Scottish Record Society, 93, Edinburgh: Neill \& Co

Dickson, T et al (eds) 1877-1978. Accounts of the Lord High Treasurer of Scotland, I3 vols, Edinburgh: HM General Register House

Donaldson, G 1949. Accounts of the Collectors of Thirds of Benefices, Edinburgh: Scottish History Society
Donaldson, G 1971. The Edinburgh History of Scotland: Fames V-fames VII, 3 vols, Edinburgh: Mercat Press

Donaldson, G 1984. 'Reformation to Covenant', in D Forrester and D Murray (eds), Studies in the History of Worship in Scotland, 33-5I, Edinburgh: T \& T Clark

Dunbar, J G 1996. 'The emergence of the reformed church in Scotland $c$ 1560-c 1700', in J Blair and C Pyrah (eds), Church Archaeology. Research Directions for the Future, I27-34, York: Council for British Archaeology

Dunlop, A I (ed) 1956. Calendar of Scottish Supplications to Rome 1423-8, Edinburgh: Scottish History Society

Gifford, J 2007. The Buildings of Scotland: Perth and Kinross, New Haven and London: Yale University Press

Gifford, J and Walker, F A 2002. The Buildings of Scotland: Stirling and Central Scotland, New Haven and London: Yale University Press

Greenhill, F A 1943-4. 'Notes on Scottish incised slabs (I)', Proc Soc Antiq Scotl, 78, 80-91

Greenhill, F A 1946-8. 'Notes on Scottish incised slabs (III)', Proc Soc Antiq Scotl, 8I, 99-II3

62. Aberfoyle, Abernyte, Balquhidder, Bendochy, Dollar, Dowally, Fortingall, Glendevon, Lethendy, Logie, Madderty, Meigle, Muckersie and Redgorton.

63. Auchtergaven, Beath, Clunie, Crieff, Dron, Kinclaven, Kinloch, Kirkmichael, Lethendy, Logierait, Madderty, Menmuir, Moneydie, Monzie, Moulin, Rattray, Ruthven, St Madoes, St Martins, Tealing, Tibbermore and Trinity Gask.

64. Callander, Killin, Kilmahog, Lecropt, Logiebide, Pitcairn, Rannoch (Killichonan), Saline and Strathmiglo. 
Grose, F I789-9I. The Antiquities of Scotland, 2 vols, London: Hooper \& Wigstead

Hannay, R K (ed) I915. Rentale Dunkeldense, Edinburgh: Scottish History Society

Hay, G 1957. The Architecture of Scottish PostReformation Churches 1560-I843, Oxford: Clarendon Press

Howard, D 1995. Scottish Architecture: Reformation to Restoration 1560-I660, Edinburgh: Edinburgh University Press

Innes, C (ed) 1847. Liber Insule Missarum, Edinburgh: Bannatyne Club

Jervise, A I882. The History and Traditions of the Land of the Lindsays in Angus and the Mearns, Edinburgh: D Douglas

Kelly, W I933-4. 'Carved oak from St Nicholas' Church, Aberdeen', Proc Soc Antiq Scotl, 68, $355-66$

Kirk, J, Tanner, R J and Dunlop, A I 1997. Calendar of Scottish Supplications to Rome 1447-7I, Edinburgh: Scottish Academic Press

Littlejohn, D (ed) 1904. Records of the Sheriff Court of Aberdeenshire, 3 vols, Aberdeen: New Spalding Club

Macdonald, A (ed) I835. Reports on the State of Certain Parishes in Scotland, Made to His Majesty's Commissioners for Plantation of Kirks, Edinburgh: Maitland Club

Macfarlane, W (ed) 1906. Geographical Collections Relating to Scotland, 3 vols, Edinburgh: Scottish History Society

McRoberts, D I959. 'Material destruction caused by the Scottish Reformation', Innes Review, 10, I26-72

McRoberts, D 1965. 'Scottish Sacrament Houses', Trans Scottish Ecclesiological Soc, 15, 33-56

McRoberts, D 197I. 'Dunblane Cathedral under the Chisholms', f Soc Friends of Dunblane Cathedral, II(2), 37-52

New Statistical Account of Scotland I834-45, I5 vols, Edinburgh and London: W Blackwood \& Sons

\section{RÉSUMÉ}

La grande majorité des églises paroissiales écossaises doivent leur aspect actuel à des reconstructions effectuées à partir de la fin du dix-huitième siècle ou au dix-neuvième siècle. Les auteurs de cette communication estiment néanmoins que, dans de nombreux cas, ces reconstructions auraient été relativement superficielles, et que l'œuvre médiévale aurait pu survivre sous ce qui n'était peut-être guère, dans certains cas, qu'un vernis moderne. Afin de mettre cette opinion à l'épreuve, fut entreprise une enquête sur tous les sites paroissiaux médiévaux dans les diocèses de Dunblane et de Dunkeld. Le résumé des résultats de cette enquête se trouve dans cette communication.
Reg Mag Sig I882. Registrum Magni Sigilli Regum Scottorum. Vol II: I4I4-1513, Edinburgh: Scotland's National Archives

Reg Mag Sig I883. Registrum Magni Sigilli Regum Scottorum. Vol III: 15I3-46, Edinburgh: Scotland's National Archives

Reg Sec Sig 1908-82. Registrum Secreti Sigilli Regum Scotorum, Edinburgh: Scotland's National Archives

Russel, M (ed) 1824. An Historical Account of the Scottish Bishops down to the year I688 by the Right Revd Robert Keith, Edinburgh and London: Bell \& Bradfurt

Sinclair, J (ed) I79I-9. Statistical Account of Scotland, 2 I vols, Edinburgh: William Creech

Spicer, A 2000. " "Defyle not Christs Kirk with your carrion": the development of burial aisles in post-Reformation Scotland', in P Marshall and P Roberts (eds), The Place of the Dead in European Society, I400-I700, I49-69, Cambridge: Cambridge University Press

Spicer, A 2003. 'Iconoclasm and adaptation: the Reformation of the churches in Scotland and the Netherlands', in D Gaimster and R Gilchrist (eds), The Archaeology of Reformation 1480-1590, 29-43, Leeds: Maney

Stuart, J (ed) I844. Extracts from the Council Register of the Burgh of Aberdeen, 1398-1570, XII, Aberdeen: New Spalding Club

Theiner, A (ed) i864. Vetera Monumenta Hibernorum et Scotorum Historiam Illustrantia, Rome: Vatican

Thomson, T (ed) I823. Vitae Dunkeldensis Ecclesiae Episcoporum ... ad Annum MDXV, Edinburgh: Bannatyne Club

Thomson, T (ed) I844. The Acts of the Parliaments of Scotland II24-I423, III, Edinburgh: Record Commission

Walker, J R I886-7. 'Scottish baptismal fonts', Proc Soc Antiq Scotl, 2I, 346-448

\section{ZUSAMMENFASSUNG}

Die meisten schottischen Pfarrkirchen verdanken ihr Aussehen den Renovierungsarbeiten, die ab dem späten achtzehnten oder neunzehnten Jahrhundert durchgeführt wurden. Der Autor dieser Abhandlung ist allerdings der Meinung, daß diese Restaurationen in vielen Fällen relativ oberflächlich ausgeführt wurden und mittelalterliche Arbeiten under den modernen Fassaden erhalten sind. Um diese These zu testen, wurde eine Bestandsaufnahme aller mittelalterlichen Pfarrkirchen in den Bistümern von Dunblane und Dunkeld durchgeführt. Die Ergebnisse dieser Bestandsaufnahme sind in dieser Abhandlung zusammengefasst. 